\title{
Crustal Structure Along Sunda-Banda Arc Transition Zone from Teleseismic Receiver Functions
}

\author{
Syuhada SYUHADA ${ }^{1,2}$, Nugroho Dwi HANANTO ${ }^{3}$, \\ Chalid I. ABDULLAH ${ }^{4}$, Nanang T. PUSPITO ${ }^{5}$, Titi ANGGONO ${ }^{1}$, \\ and Tedi YUDISTIRA ${ }^{5}$
}

${ }^{1}$ Graduate Research on Earthquake and Active Tectonics (GREAT), Bandung Institute of Technology (ITB), Bandung, Indonesia; e-mail: syuhada@lipi.go.id

${ }^{2}$ Research Centre for Physics - Indonesian Institute of Sciences (LIPI), Tangerang Selatan, Indonesia

${ }^{3}$ Research Centre for Geotechnology - LIPI, Bandung, Indonesia ${ }^{4}$ Faculty of Earth Sciences and Technology, ITB, Bandung, Indonesia ${ }^{5}$ Faculty of Mining and Petroleum Engineering, ITB, Bandung, Indonesia

\section{Abstract}

We analyzed receiver function of teleseismic events recorded at twelve Indonesian-GEOFON (IA-GE) broadband stations using nonlinear Neighbourhood Algorithm (NA) inversion and $H-k$ stacking methods to estimate crustal thickness, $V p / V s$ ratios and S-wave velocity structure along Sunda-Banda arc transition zone. We observed crustal thickness of 34-37 km in Timor Island, which is consistent with the previous works. The thick crust $(>30 \mathrm{~km})$ is also found beneath Sumba and Flores Islands, which might be related to the arc-continent collision causing the thickened crust. In Timor and Sumba Islands, we observed high $V p / V s$ ratio $(>1.84)$ with low velocity zone that might be associated with the presence of mafic and ultramafic materials and fluid filled fracture zone. The high $\mathrm{Vp} / \mathrm{Vs}$ ratio observed at Sumbawa and Flores volcanic Islands might be an indication of partial melt related to the upwelling of hot asthenosphere material through the subducted slab.

Key words: Receiver function, crustal structure, Sunda-Banda arc transition zone. 


\section{INTRODUCTION}

The Sunda-Banda Arc transition zone has been known as one of the most complicated tectonic setting in the world providing one the best modern examples of the early stages of transition from subduction to arc-continent collision (Fig. 1). It developed as a consequence of the interaction between the Australian lithosphere and the Banda Arc in the Pliocene (Hall and Smyth 2008). The structural evolution of this area is characterized by different tectonic episodes including rifting of Timor, Savu Basin and Sumba evolution. This complicated tectonic setting causes this area to be an ideal place to study the lithologic changes in crustal structures associated with the deformation along the plate boundary. A number of studies have been conducted to elucidate the geodynamic and tectonic evolution of the region (Bowin et al. 1980, Milsom and Audley-Charles 1986, Shulgin et al. 2009). However, information regarding the deep crustal structure of this region is less studied, which is critical to complete our understanding of the geodynamic evolution of the region. Most of the crustal studies were focused on the small part of the region through gravity modelling, seismic reflection and wide-angle

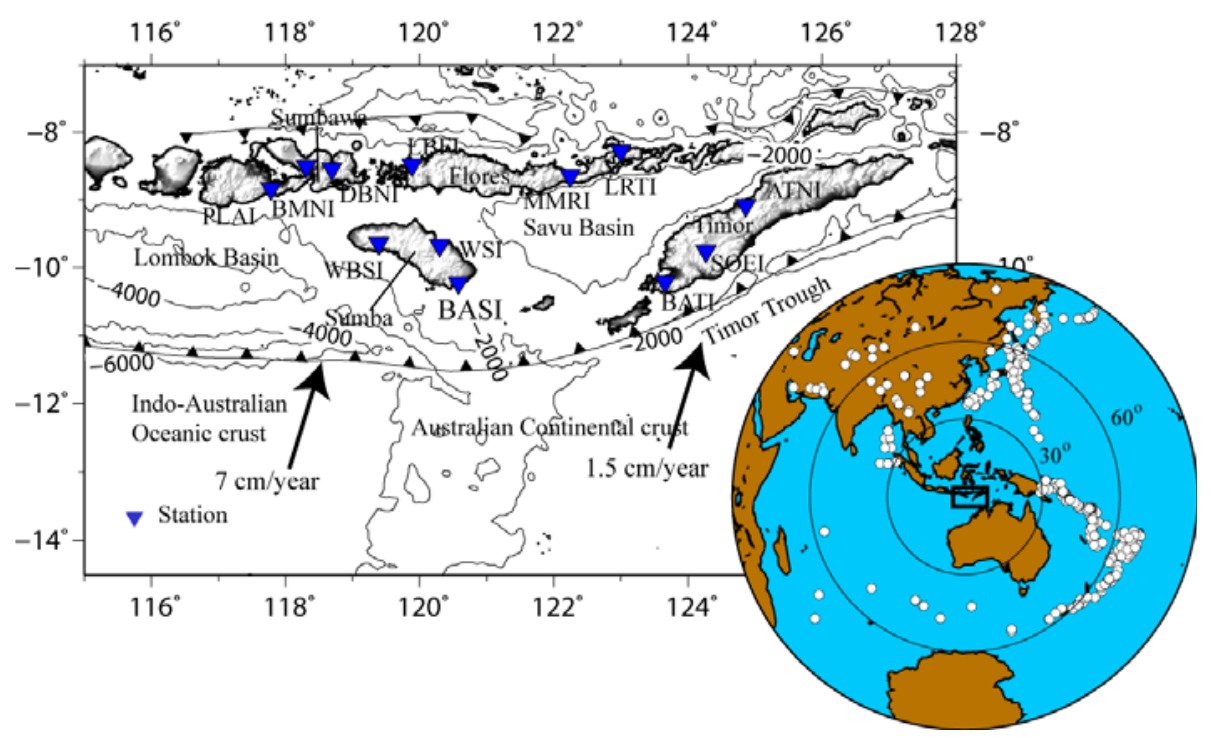

Fig. 1. The tectonic setting of the study area showing the change in tectonic regime from subduction to collision. The inverted blue triangles represent the seismic stations used for the study. The bathymetric contours are marked by the grey lines (Sandwell and Smith 2009). The globe on the right bottom depicts the distribution of teleseismic events used in this study (magnitude greater than 6 and epicentral distance between $30^{\circ}$ and $90^{\circ}$ ). The black solid box represents the study area on the larger map. 
refraction studies. For example, gravity modelling has been conducted in Timor Island indicating that the Moho depth in this island ranges from 30 to $40 \mathrm{~km}$ (Milsom and Audley-Charles 1986, Bowin et al.1980, Kaye 1989). he marine seismic reflection study conducted by Shulgin et al. (2009) in the east of Sumba reveals 12-15 thick crust representing the continental character of the Australian lithosphere continuous through the outer Banda arc. The combined analysis of seismic wide-angle refraction, multichannel streamer and gravity data also has been conducted in south of Lombok, suggesting the significant changes in the incoming crustal structure which ranges from $7 \mathrm{~km}$ thick of oceanic crust offshore Lombok (Planert et al. 2010) to $12 \mathrm{~km}$ thick crystalline crust of the Australian continental margin (Shulgin et al. 2009).

Receiver function analysis is a method using teleseismic event to extract structure information beneath a station. This technique has been widely used as a powerful tool in characterizing the crustal structure as well as determining the Moho depth in various tectonic environments. For example, Zhu and Kanamori (2000) applied a grid-search method using receiver function data to estimate the Moho depth variation and Poisson's ratio in Southern California, USA. Bannister et al. (2004) derived the velocity structure from the inversion of receiver function beneath seismic stations in the volcanically active region, North Island, New Zealand. Ahmed et al. (2014) imaged crustal thickness variation from computed receiver function in the eastern Gulf of Aden continental margins.

In recent years, the installation of seismic broadband stations around Banda-Arc transition zone may enable us to study crustal structure through receiver function method for the larger scale coverage of the Sunda-Banda arc transition zone. In this study, we use receiver function analysis to determine the regional variation of the crustal properties (the Moho depths, $V p / V s$ ratios and $\mathrm{S}$-wave velocity models) along the transition zone from subduction to collision using teleseismic receiver function. The study provides new insight into the tectonic development and the processes involved in the transition zone.

\section{DATA AND METHODS}

We analyzed body wave seismograms obtained from teleseismic events recorded by twelve Indonesian-GEOFON (IA-GE) stations from 2005 to 2014. The twelve seismic stations are distributed in four main islands (Sumbawa, Flores, Sumba and Timor islands) around the Sunda-Banda transition zone reflecting the diverse geologic and tectonic setting (Fig. 1). We selected teleseismic events from ISC catalogue with epicentral distance $30^{\circ}-90^{\circ}$ and magnitude greater than 6 (Fig. 1). This distance range is used to avoid the contamination from regional and core phases and to assure that incoming waves have steep incidence angles. Furthermore, the large moment magni- 
tude selection for the teleseismic events provides waveforms with good signal to noise ratio (Macpherson et al. 2012).

The seismograms were pre-processed into the following steps. First, the three component seismograms were inspected manually to select the best quality records as well as to pick the P-arrivals. The seismograms used are baseline-corrected by subtracting the mean and removing the instrument response. The pairs of horizontal components (north-south and east-west components) for each event were then rotated into radial-transverse components. Finally, we selected the time windows started $10 \mathrm{~s}$ before and $50 \mathrm{~s}$ after the P-wave arrival.

We computed receiver functions in the time domain using the iterative deconvolution technique developed by Ligorria and Ammon (1999) with 500 iterations. This method provides more stable solutions of the receiver functions for noisy data compared to the conventional deconvolution method in frequency domain. We applied the Gaussian filter to control the high frequency noise of the receiver function. After trial and error with different values, we set the Gaussian filter with bandwidths of 1.5. The bandwidth attenuates the frequency contents greater than approximately $0.75 \mathrm{~Hz}$. A least-square misfit criterion was then used as assessment for the quality of receiver function resulted from the iterative deconvolution process. The misfit was computed from the difference between the observed radial seismogram and the calculated receiver function convolved with the observed vertical seismogram. The receiver functions which have more than $90 \%$ waveform fit were then used for further analysis.

In total, we obtained 800 individual receiver functions from 354 events which are mostly from N-NE and E-SE directions. The radial and transverse receiver functions were then plotted as a function of the source backazimuth to identify the presence of the complex structure (e.g., dipping interfaces, crustal scattering sources and anisotropic bodies) beneath the stations. The plots of the receiver functions with respect to the event backazimuth for each station are shown in Figs. 2, 3 and a series of figures in the Appendix (Figs. A1-A4). We observed that the radial receiver functions of some stations (e.g., MMRI and LBFI) show strong azimuthal variations in amplitude and time of the Moho PS arrival, indicating the presence of dipping interfaces (e.g., Zheng et al. 2005, Linkimer et al. 2010). Because station MMRI exhibits the most acceptable coverage in backazimuth, we used the receiver functions from this station to illustrate how the amplitude of the PS conversion varies with backazimuth (Fig. 2). We found that receiver functions at this station show a strong PS arrival at $\sim 6 \mathrm{~s}$ for the earthquakes arriving from $0^{\circ}-75^{\circ}$ and $230^{\circ}-360^{\circ}$, and at $\sim 5 \mathrm{~s}$ for the earthquakes arriving from 


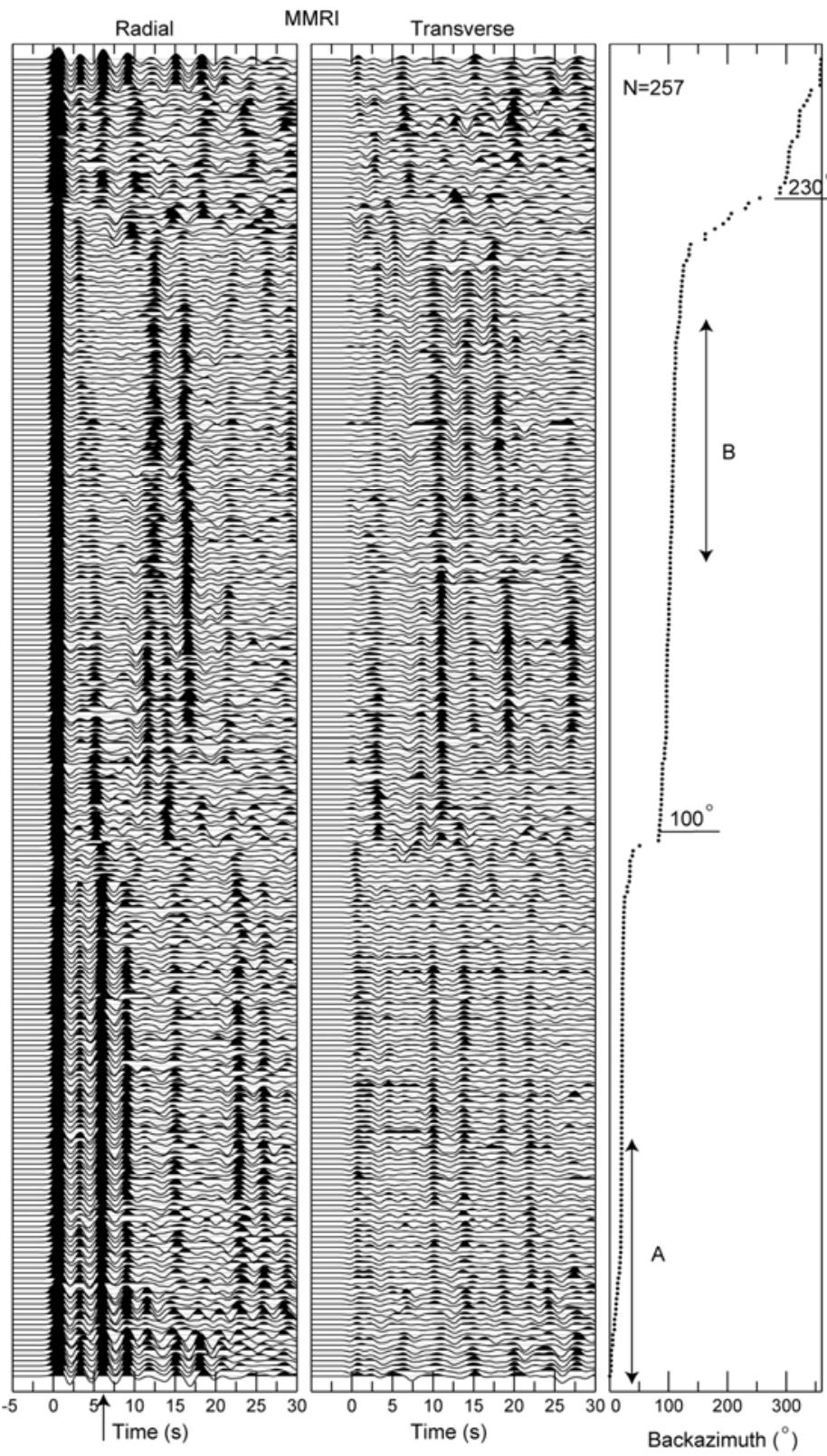

Fig. 2. Receiver functions computed at station MMRI plotted with equal spacing as a function of backazimuth. The black arrow in the left panel marks the PS phase. A and $\mathrm{B}$ in the right panel denote the teleseismic events coming from N-NE and E-SE directions, respectively. The $\mathrm{N}$ value on top of the right panel represents the total number of receiver functions used for the analysis at the station. 

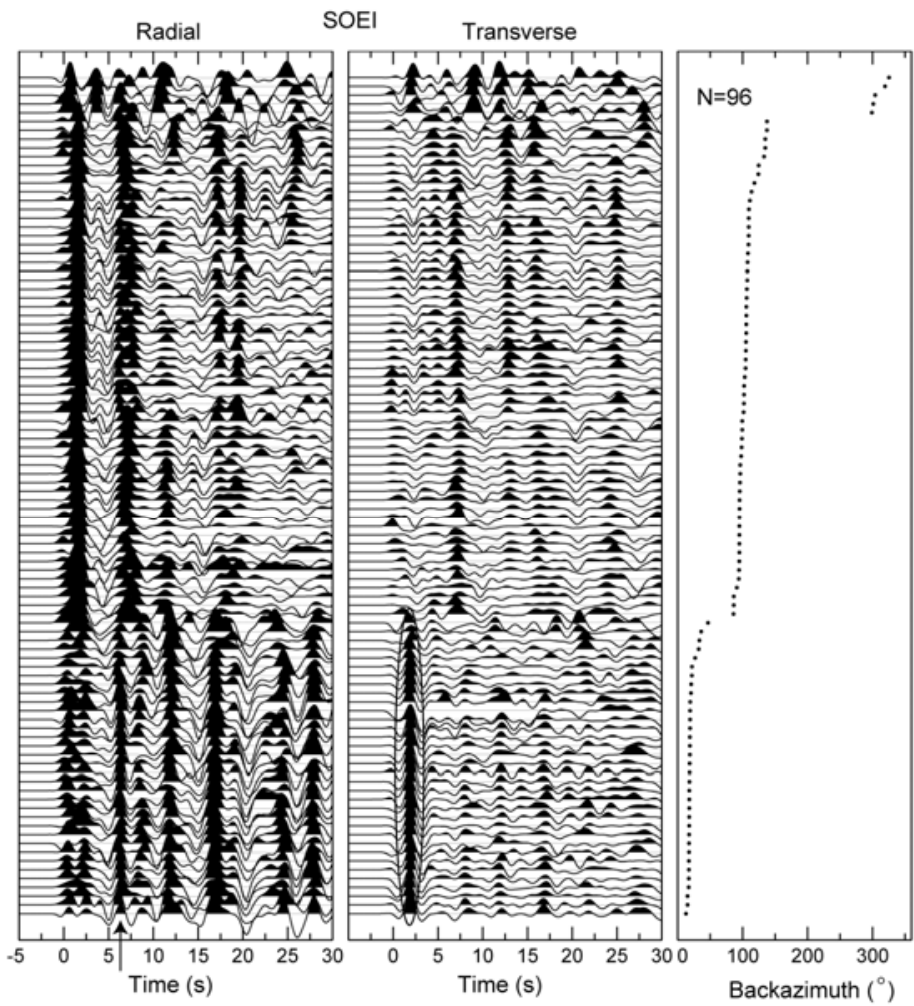

Fig. 3. Receiver functions computed at station SOEI plotted with equal spacing as a function of backazimuth. The black arrow in the left panel marks the P-to-S phase. The black ellipse in the mid panel marks the large amplitude arrivals on the transverse receiver functions. $\mathrm{N}$ value on the top of the right panel represents the total number of traces used for the analysis at the station.

$\sim 100^{\circ}-120^{\circ}$ backazimuth. The weak or unclear PS arrival is observed for the receiver functions obtained from the earthquakes located at the $120^{\circ}-230^{\circ}$.

We also found that some stations (e.g., SOEI, ATNI and BATI) exhibit relatively large amplitude arrivals on the transverse receiver functions (Figs. 3 and A1) suggesting the presence of complex structure such as dipping layers, sources of crustal scattering and anisotropy (e.g., Levin and Park 1998, Jones and Phinney 1998). Since we only used the radial receiver functions for our subsequent analysis and the amplitude of the main signals in the radial receiver functions is larger than that in the transverse receiver functions, thus, the velocity model obtained from the $1 \mathrm{D}$ inversion is still considered valid (Darbyshire 2003). In addition, the receiver functions at each site were stacked to suppress random background noise and to enhance 
the main signal, as well as to reduce the 3-D effects due to lateral structure variation and to provide an average crustal model (Zhu and Kanamori 2000).

Stacked receiver functions in radial components from all stations used in this study are shown in Fig. 4. The number of receiver functions for the stacking varies from about 16 to 257 at each individual station. The quality of the stacks may depend on the number of receiver functions at each station, similarity and coherence signal from subsurface structure on the receiver functions derived from different events at the same station and stability of the computed receiver function (Spasojevic and Clayton 2008). Stacking N number of traces will improve the signal to noise ratio by a factor of $\sqrt{\mathrm{N}}$ (Owens 1984). We found that some stations (e.g., BMNI and WSI) have fewer traces compared to other stations, which may affect to the quality of the stacked receiver function. However, we observed that the Moho P to S
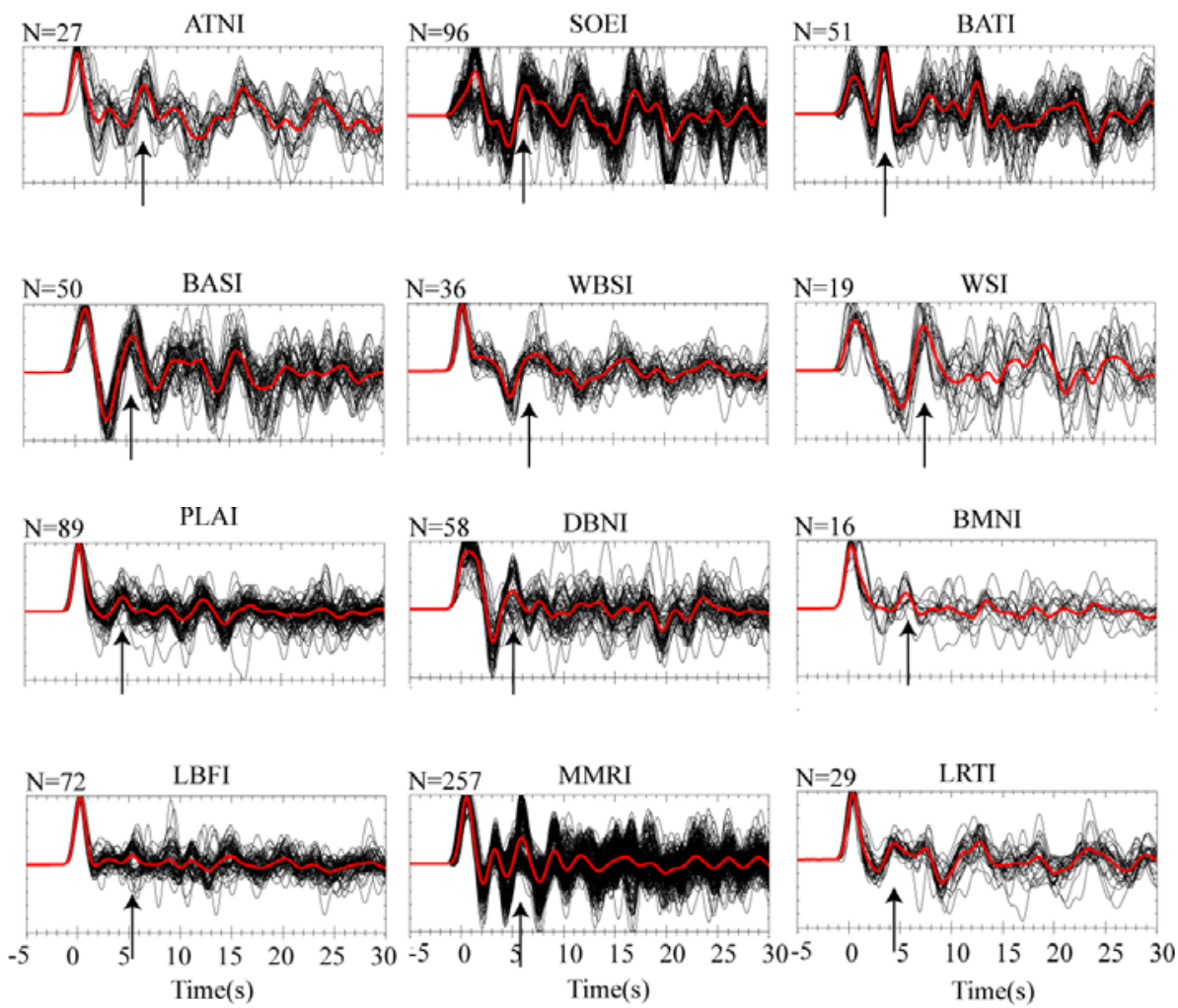

Fig. 4. The stacked radial receiver functions for all stations used in this study are represented by thick red lines. The individual receiver functions are shown by thin black lines and the Moho arrivals are marked by black arrows. The number of traces in each stack is indicated by $\mathrm{N}$ value on left top of each panel. 
phase is still clearly visible on the stacked receiver functions for those stations.

The stacked receiver function at some seismic stations, such as SOEI and BATI, show time delay on the initial P pulse of the radial receiver functions, indicating the existence of the near surface sedimentary layer beneath the stations. The shift in the direct $\mathrm{P}$ pulse (from zero time) is caused by the superposition of the direct $\mathrm{P}$ and PS phases generated at the sediment-bedrock interface and cannot be removed by filtering process (e.g., Cassidy 1992, Julia et al. 2008). We also observed that the negative pulses after the direct $\mathrm{P}$ pulse with large amplitude are quite apparent on the stacked radial receiver functions at some seismic stations (e.g., WBSI, WSI and SOEI), which may indicate the presence of any low velocity layer in the mid crust. The effect of such a low velocity layer on receiver functions has been observed and modelled for other regions, for instance, by Bannister et al. (2004). Another prominent feature in the averaged radial receiver functions is the Moho $\mathrm{P}$ to $\mathrm{S}$ converted phase, which is generally apparent in some stacked radial receiver functions at around 5-7 s. However, few seismic stations also exhibit unclear or small amplitude for the Moho P-S phase on the receiver function (e.g., station LBFI). The amplitude of the Moho $\mathrm{P}$ to $\mathrm{S}$ converted phase in a receiver function depends on the incident angle of the incoming $\mathrm{P}$ wave and the size of the velocity contrast generating the converted wave and its multiples (Ammon 1991).

Due to limitation on geophysical information about crustal structures in this region that can be used as a reference to assess the consistency of the receiver function analysis, we employed two inversion methods in this study. Firstly, the neighbourhood algorithm technique of Sambridge (1999) was utilized to derive the $\mathrm{S}$ wave velocity structure beneath the seismic station. To estimate the $\mathrm{S}$ wave velocity profiles of the crust and uppermost mantle through the inversion process, first, we stacked all radial receiver functions at each station to enhance the signal to noise ratio. For the inversion process, we selected the receiver function's time window from $5 \mathrm{~s}$ before the direct $\mathrm{P}$ wave arrival to $25 \mathrm{~s}$ after it. This time window was chosen to assure that all crustal and lithosperic phase arrivals were included in the analysis. In this study, we inverted the stacked receiver functions using the non-linear neighbourhood algorithm (NA) (Sambridge 1999). This technique is a fully nonlinear approach based on random choice of model samples to search the optimum model using the misfits of the previous models. We divided the crustal structure for the inversions into six horizontal layers: sediment, basement, upper crust, middle crust, lower crust and upper mantle. Each layer contains four parameters describing the thickness of the layer $(\mathrm{km}), V p / V s$, the Swave velocity at the top and bottom of each layer. That provides 24 parameters (4 parameters in each layer). We set the tuneable parameters after a 
number of trials for each inversion involving 2000 iterations, providing 40,020 velocity models. A large range of initial random seeds and velocity profile parameterizations are set to exploit the dependence of the inversion to the initial choice of model samples.

Secondly, the Zhu and Kanamori (2000) $H-k$ stacking method was applied to estimate the average of crustal thickness $(H)$ and $V p / V s$ ratio $(k)$. We assumed that the crust and upper mantle are isotropic with a flat-lying planar interface due to the limited backazimuthal coverage of the data, which also prevents us from analysing the effect of anisotropy using receiver functions. We applied this $H-k$ stacking procedure for the receiver functions to estimate the average thickness $(H)$ and $V p / V s$ ratio $(k)$ of the crust beneath the stations as well as to test the consistency of the NA inversion results. The method sums the amplitudes of the PS signal and the multiples PPPS and PPSS + PSPS within given range of $H$ and $k$ values using the stacking function. The maximum value resulted from this coherent stack then provides the best estimate of crustal thickness $(H)$ and $V p / V s$ ratio $(k)$ at particular station. The advantage using this analysis is that it does not require subjective picking of arrival times of the Moho PS converted phase and its multiple phases. It is necessary to note that this method is only valid in the case of simple crust. In the case of complex structural crust such as the presence of anisotropic or dipping structure and near surface sedimentary layers, this conventional $H-k$ staking method may provide ambiguous estimates of crustal thicknesses and $V p / V s$ ratios (Eagar 2011). Some stations in this region are situated in the place where sediment inclusions may dominate the near surface layer. The presence of sediment layer causes the delay arrival time of the direct P signal and the primary Moho conversion phase on the low frequency receiver function, as shown in Fig. 4. Therefore, in order to minimize the sediment effect to the $H-k$ grid-searching analysis, we employed the two layer $H-k$ stacking method developed by Yeck et al. (2013). The method requires the information about the sediment thickness and its $V p / V s$ ratio beneath the seismic stations. The estimated sediment thickness and $V p / V s$ ratio is then applied to correct the arrival of the subsediment interface converted phases using time adjustments due to the presence of sediments (Yeck et al. 2013). In this $H-k$ analysis, we employed the values of the sediment thickness and its $V p / V s$, the sediment $\mathrm{P}$ wave velocities and the average crustal velocities previously obtained from the NA-inversion.

To assess the accuracy and stability of stacking analysis, we employed bootstrap stacking of the receiver functions for each station using the same procedure as reported by Eagar and Fouch (2012). The bootstrap sampling technique produces a random sample with replacement from the original data (Efron and Tibshirani 1986, 1991). Here, we constructed 1000 resampled data sets selected at random from the original receiver function data set. The 
value of $H$ and $k$ were determined for every resampled data. We then calculated the mean and standard deviation of the resulting parameters.

\section{RESULTS}

\subsection{S-wave velocity profiles}

S-wave velocity models obtained from the inversion for stations located in Timor Island: ATNI, SOEI and BATI are shown in Fig. 5. The inversion result for station ATNI shows S velocities of $\sim 2-3 \mathrm{~km} / \mathrm{s}$ near the surface, then increasing to $3.2 \mathrm{~km} / \mathrm{s}$ at $10 \mathrm{~km}$ depth. The mid crust in this station is observed at $\sim 10-26 \mathrm{~km}$ depth with average $V s$ of $3.3 \mathrm{~km} / \mathrm{s}$. At $26-34 \mathrm{~km}$ depth, the velocity profile indicates a low-velocity zone in the lower crust, with an $\mathrm{S}$-wave velocity as low as $\sim 2.6 \mathrm{~km} / \mathrm{s}$. The Moho beneath this station is estimated at a depth of $\sim 37 \mathrm{~km}$, where the S-wave velocity reaches $4.0 \mathrm{~km} / \mathrm{s}$. For station SOEI, located to the west of ATNI, the inversion results indicate $\mathrm{S}$ wave velocity of $\sim 1-2.5 \mathrm{~km} / \mathrm{s}$ at the surface, increasing to $\sim 3.2-3.4 \mathrm{~km} / \mathrm{s}$
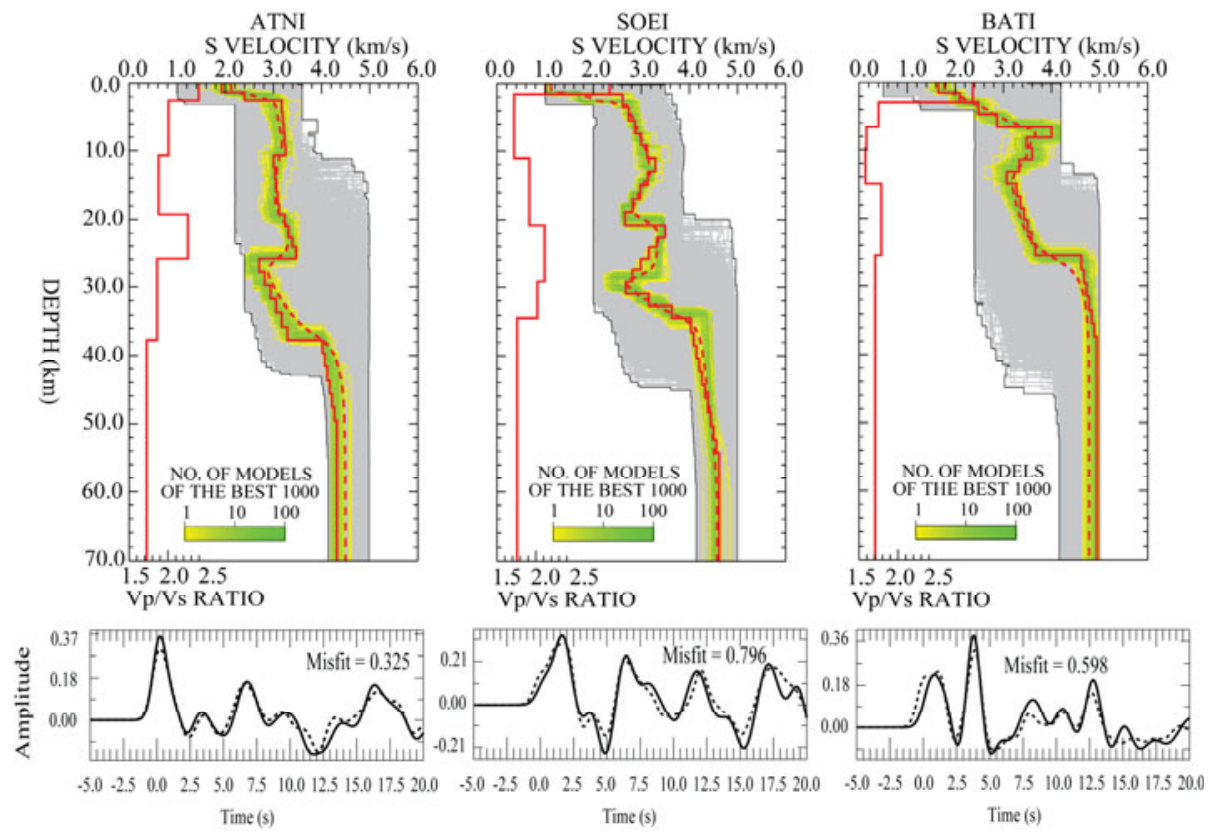

Fig. 5. S wave velocity models for seismic stations located in Timor Island derived from the non-linear inversion. The dashed and solid red lines represent the average and the best fitting model, respectively. The grey shaded area indicates all models (40 020 models) searched in the inversion. The red line on the left represents the best fitting $V p / V_{s}$ ratio. Bottom panels show the predicted and observed receiver function indicated by dashed and solid black lines, respectively. 
at $10 \mathrm{~km}$ depth and fluctuating down to $\sim 29 \mathrm{~km}$ depth. The $\mathrm{S}$ velocity then increases and becomes larger than $4 \mathrm{~km} / \mathrm{s}$ below $\sim 34 \mathrm{~km}$ depth, reflecting the mantle velocities beneath the station. The low-velocity zone is also observed in the lower crust beneath this station at a depth between $\sim 20-34 \mathrm{~km}$ with Swave velocity as low as $\sim 2.8 \mathrm{~km} / \mathrm{s}$. The average $V p / V s$ ratio obtained from the inversion is relatively high for the entire crust for both stations, ATNI and SOEI, which are $\sim 1.9$ and $\sim 2.0$, respectively. For station BATI, situated in the southwestern part of the island, the S velocity is less than $2 \mathrm{~km} / \mathrm{s}$ at the first $2 \mathrm{~km}$ depth, then increases to $4.0 \mathrm{~km} / \mathrm{s}$ at $6.0-7.0 \mathrm{~km}$ depth. Uppermost mantle velocity is reached at $28 \mathrm{~km}$ depth. The crustal $\mathrm{Vp} / \mathrm{Vs}$ ratio in this station is lower $(\sim 1.7)$ compared to those at other stations.

The $\mathrm{S}$ wave velocity profiles derived from the non-linear inversion for the Sumba stations, BASI, WBSI and WSI, are shown in Fig. 6. At station BASI, the near surface is covered by low velocity material with a velocity less than $2 \mathrm{~km} / \mathrm{s}$. The velocities increase rapidly to $3.8 \mathrm{~km} / \mathrm{s}$ down to $10 \mathrm{~km}$ depth, and then decrease slightly to $\sim 3.2-3.4 \mathrm{~km} / \mathrm{s}$ at a depth between $\sim 14 \mathrm{~km}$ and $24 \mathrm{~km}$. The Moho discontinuity is estimated at $\sim 36 \mathrm{~km}$ depth
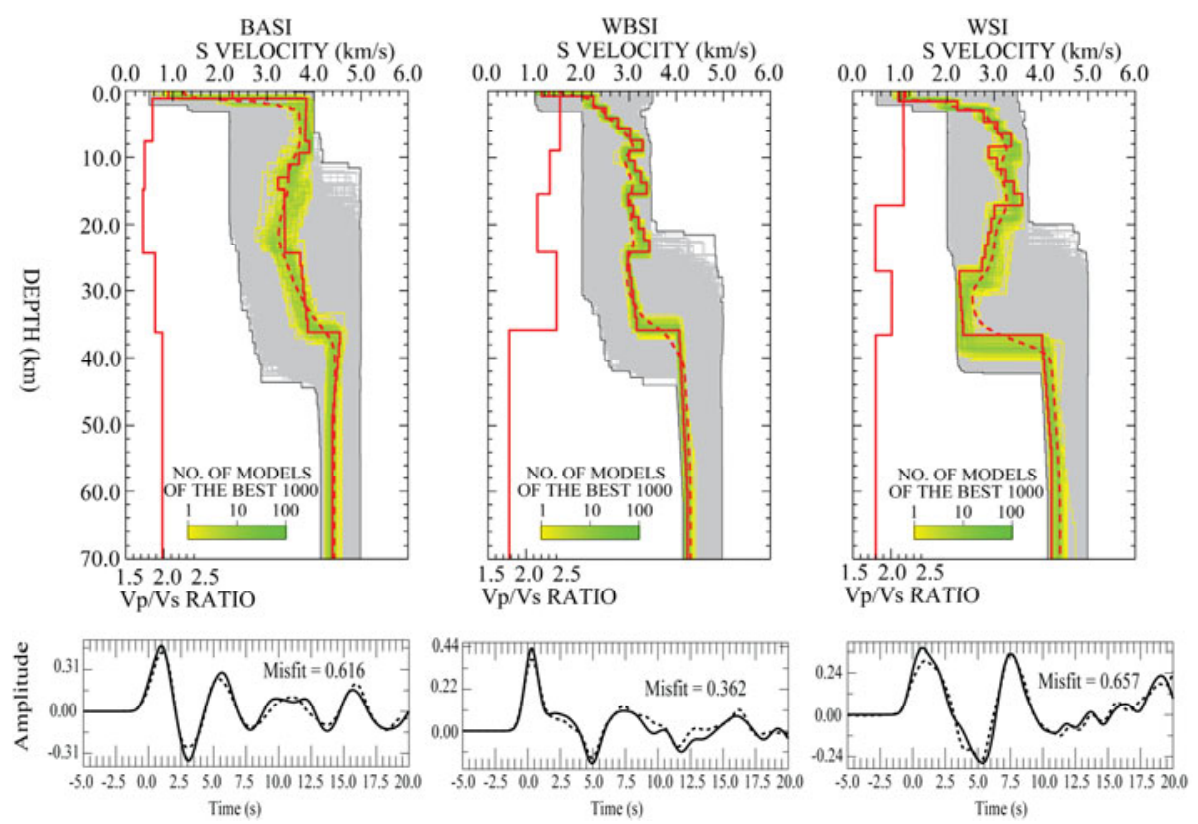

Fig. 6. S wave velocity models for seismic stations located in Sumba Island derived from the non-linear inversion. The dashed and solid red lines represent the average and the best fitting model, respectively. The red line on the left represents the best fitting $\mathrm{Vp} / \mathrm{Vs}$ ratio. 
with $\mathrm{S}$ velocities higher than $4.2 \mathrm{~km} / \mathrm{s}$. At station WBSI, the model indicates that the $\mathrm{S}$ wave propagates with a velocity less than $2 \mathrm{~km} / \mathrm{s}$ at the near surface, then increasing to $\sim 3 \mathrm{~km} / \mathrm{s}$ at $10 \mathrm{~km}$ depth. The model also reveals a modest negative velocity gradient that corresponds to a velocity of $\sim 2.9 \mathrm{~km} / \mathrm{s}$ at depths between $\sim 24-36 \mathrm{~km}$. Below $36 \mathrm{~km}$, the velocity increases to $\sim 4.2 \mathrm{~km} / \mathrm{s}$ reflecting the $\mathrm{S}$ wave velocity of the mantle. The velocity profile for station WSI is started with the low near surface velocity layer with a velocity less than $1 \mathrm{~km} / \mathrm{s}$. In this profile, we also observed the presence of low velocity zone at a depth of $20-35 \mathrm{~km}$, characterized by a strong negative velocity gradient with a minimum velocity of $2.2 \mathrm{~km} / \mathrm{s}$. The crust-mantle transition is observed at a depth below $36 \mathrm{~km}$ marked by a positive velocity gradient. In addition, another interesting feature from the velocity profiles for the Sumba stations (especially at station WBSI and WSI) is that the $V p / V s$ ratio is relatively high $(>2)$ in the lower crust where the low-velocity zones are also observed.

Inversion results for stations PLAI, DBNI and BMNI, which are located in Sumbawa Island, are shown in Fig. 7. The solutions of the inversion for the three stations have similar characteristics at the near surface with low ve-
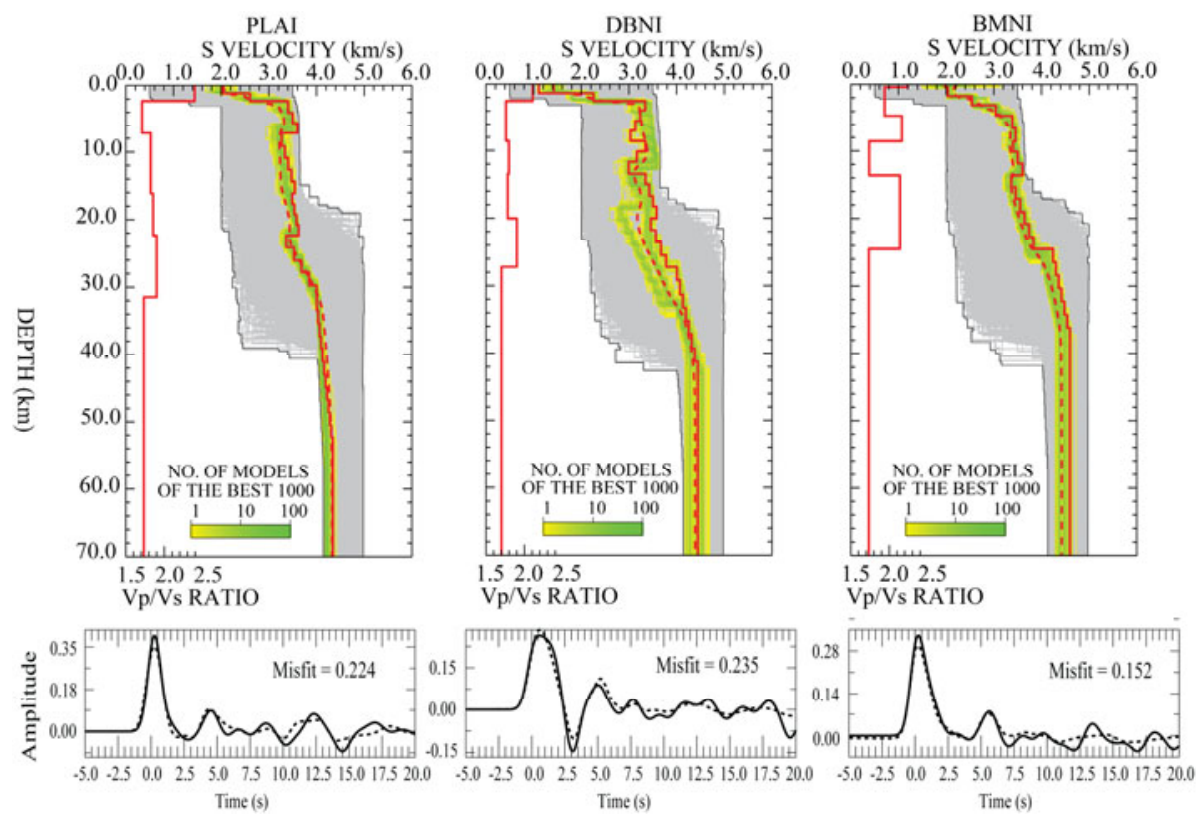

Fig. 7. S wave velocity models for seismic stations located in Sumbawa Island derived from the non-linear inversion. The dashed and solid red lines represent the average and the best fitting model, respectively. The red line on the left represents the best fitting $V p / V s$ ratio. 
locity below $2 \mathrm{~km} / \mathrm{s}$. Slightly negative velocity gradients are observed in the mid crust beneath the three stations. The velocities appear to reach mantlecrust discontinuity layer at depths of $\sim 30,28$, and $27 \mathrm{~km}$ for station PLAI, DBNI and BMNI, respectively. The $V p / V s$ ratios are high $(>1.84)$ for all seismic stations. Furthermore, we observed that although the velocity model obtained for station BMNI is produced by inverting the stacked receiver functions consisting of only few traces (16 traces), the waveform misfit between the synthetic waveform and the observed radial receiver function is quite reasonable. Figure 8 displays $\mathrm{S}$ wave velocity profiles obtained from the non-linear inversion for stations located in the Flores Island, namely LBFI, MMRI and LRTI. At station LBFI, the inversion solution shows a low S wave velocity of $\sim 2 \mathrm{~km} / \mathrm{s}$ near the surface indicating the presence of sediment layer. The velocity increases gradually and seems to reach mantle velocities of $\sim 3.7 \mathrm{~km} / \mathrm{s}$ at $30 \mathrm{~km}$ depth, even though the crust-mantle transition is not well resolved. For station MMRI, the low velocity of less than $2 \mathrm{~km} / \mathrm{s}$ is observed at the near surface. The velocity then increases to about $3.4 \mathrm{~km} / \mathrm{s}$ at $10 \mathrm{~km}$ depth. The modest low velocity zone is observed between 12 and $22 \mathrm{~km}$ depth and Moho is detected at a depth of 32-34 km. For station LRTI,
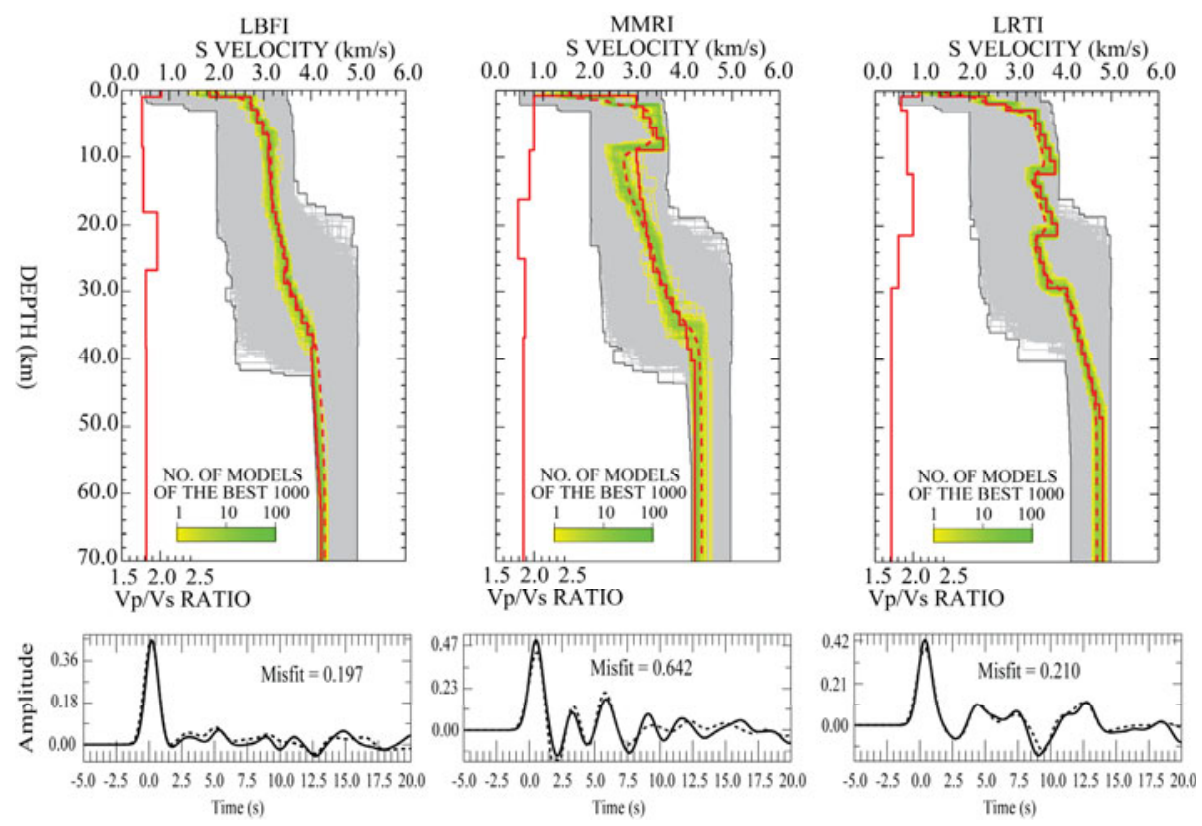

Fig. 8. S wave velocity models for seismic stations located in Flores Island derived from the non-linear inversion. The dashed and solid red lines represent the average and the best fitting model, respectively. The red line on the left represents the best fitting $V p / V s$. 
we observed that the $\mathrm{S}$ wave velocity fluctuates down to Moho depth at $\sim 35 \mathrm{~km}$ depth. The high $V p / V s$ ratios are found in the crust beneath these three stations.

It is important to note that we found the difficulties in modelling the stacked receiver function for some stations where the complex structure is present. As discussed earlier, some stations (e.g., ATNI, SOEI and BATI) exhibit the high level of energy on the transverse receiver functions, which indicates the presence of complex structure such as sources of crustal scattering and anisotropy (e.g., Levin and Park 1998, Jones and Phinney 1998). Strong backazimuth variations in amplitude and time of PS arrival are also observed on the radial receiver functions for some stations, which suggest the presence of dipping structures (e.g., Zheng et al. 2005, Linkimer et al. 2010). We note that although the stacked receiver function for some stations (e.g., MMRI and SOEI) consists of reasonable number of traces, the inversion result shows poor inversion solution. A number of trials involving a range of incidence angles, and a range of model parameters have been used to improve the waveform fit on these stations, but we still obtained unsatisfactory solutions. However, the waveform fits are generally quite reasonable, matching the initial PS phases in the first 5-6.5 s, but poorly matching the later phases. This suggests that the interpretation for the crustal model may still be valid.

\subsection{Crustal thickness and $V p / V s$ ratio}

The results of the crustal thickness and $V p / V s$ ratio estimation computed from the $H-k$ stacking method for all stations used in this study are summarized and depicted in Table 1 and Fig. 9, respectively. In general, the Moho depth and $V p / V s$ ratio computed from $H-k$ stacking method are comparable with those obtained from the non-linear inversion. At stations ATNI and SOEI located in Timor Island, the $H-k$ analysis resulted in similar Moho depth of $\sim 33-35 \mathrm{~km}$ with $V p / V s$ ratio ranging from 2 to 2.2. We observed that at station BATI, located to the west of ATNI and SOEI stations, the Moho depth is shallower, that is, about $27 \mathrm{~km}$. We found that receiver functions at station BATI contain unusual strong reflection at 3-4 s and the amplitude is higher than the direct $\mathrm{P}$ amplitude. This strong reflection may cause ambiguity in the measurement and we will discuss this in the following section. Hence, we suggest that this could cause bias in the $H-k$ analysis. In Sumba Island, we inferred the comparable Moho depth of $\sim 32-36 \mathrm{~km}$ at all seismic stations. The $V p / V s$ ratios in this island are relatively high, varying between 1.88 and 2.4. We also observed consistent Moho depth with high $V p / V s$ (1.9-2.2) beneath seismic stations in Sumbawa Island, which 
have $\sim 28 \mathrm{~km}$ deep Moho. The Moho depth obtained for Flores Island ranges from $\sim 28$ to $34 \mathrm{~km}$ with consistent $V p / V s$ around $\sim 1.95$.
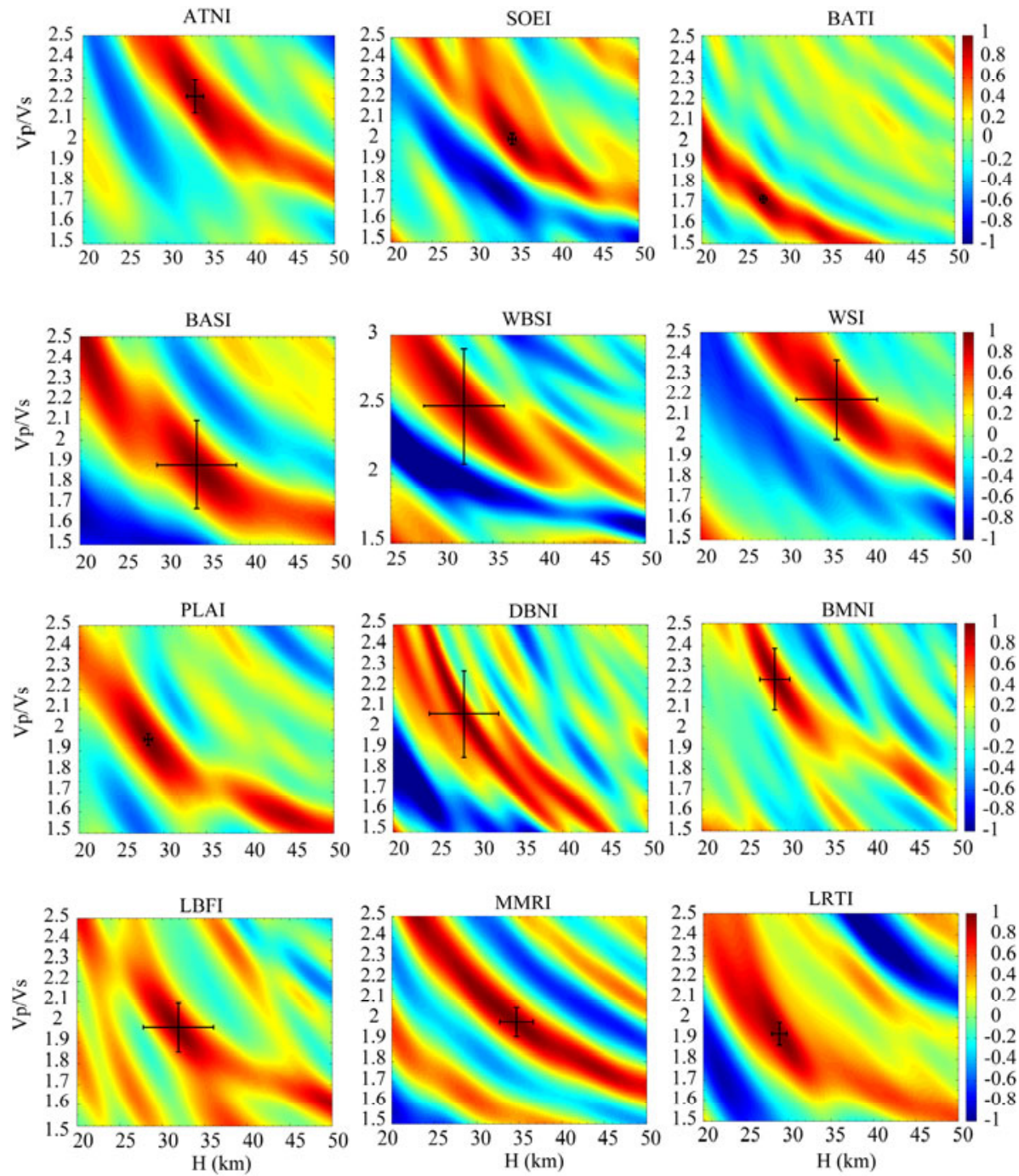

Fig. 9. Results of $H-k$ stacking analysis to search the best estimate of crustal thickness and $V p / V s$ ratio for all stations. The black crossbars indicate the maximum stacking amplitude. Small and large crossbars represent the uncertainty of measurements derived from the bootstrap sampling method. 
Table 1

Summary of the crustal thickness and $V p / V s$ with bootstrap error obtained from $H-k$ stacking analysis

\begin{tabular}{|c|c|c|c|c|}
\hline Island & Station & $\begin{array}{c}\text { Crustal thickness } \\
H[\mathrm{~km}]\end{array}$ & $V p / V s$ ratio & $\begin{array}{c}\text { Number } \\
\text { of records }\end{array}$ \\
\hline Timor & ATNI & $33.36 \pm 1.00$ & $2.21 \pm 0.08$ & 27 \\
& SOEI & $34.67 \pm 0.45$ & $2.01 \pm 0.03$ & 96 \\
& BATI & $27.28 \pm 0.39$ & $1.71 \pm 0.02$ & 51 \\
Sumba & BASI & $33.73 \pm 4.68$ & $1.88 \pm 0.21$ & 50 \\
& WBSI & $32.19 \pm 3.94$ & $2.49 \pm 0.42$ & 36 \\
& WSI & $36.04 \pm 4.77$ & $2.18 \pm 0.19$ & 19 \\
Sumbawa & PLAI & $28.16 \pm 1.95$ & $1.95 \pm 0.03$ & 89 \\
& DBNI & $28.35 \pm 4.07$ & $2.07 \pm 0.21$ & 58 \\
& BMNI & $28.58 \pm 1.76$ & $2.24 \pm 0.15$ & 16 \\
& LBFI & $31.91 \pm 4.14$ & $1.97 \pm 0.12$ & 72 \\
& MMRI & $34.67 \pm 1.96$ & $1.99 \pm 0.07$ & 257 \\
& LRTI & $28.95 \pm 0.88$ & $1.92 \pm 0.05$ & 29 \\
\hline
\end{tabular}

\section{DISCUSSION}

We analysed receiver functions using two different methods, the NA-nonlinear inversion and the $H-k$ stacking analysis, to estimate the velocity structures, $V p / V s$ ratios and the average of crustal thickness beneath seismic stations along the Sunda-Banda Arc transition zone. In general, the results obtained from the two methods indicate the consistency and robustness of the measurements.

\subsection{Timor Island}

Timor Island is fold-thrust mountain built during initial stage of the arccontinent collision (Harris and Audley-Charles 1987). The geological structure of the island is complex, involving widely different rock types such as sediment derived from an accretionary wedge, metamorphic rocks including high pressure types, ophiolites and continental crystalline fragments (Barber et al. 1977, Barber 1981, Charlton 1989). This complicated structure results from the collision of the Australian continent margin with the Banda arc. In the near surface, the island is generally covered by thick sediment deposited up to $2.5 \mathrm{~km}$ depth since $5.5 \mathrm{Ma}$ (Haig 2012). In the deeper part of the crust, beneath station ATNI and SOEI, the results obtained from the NA-inversion 
and $H-k$ stacking indicate the presence of material with relatively high $\mathrm{Vp} / \mathrm{Vs}$ ratios. The low and high $V p / V s$ ratio values represent the average crustal composition and they depend mainly on the lithology, the presence of partial melting, temperature, cracks and pore fluid (Fountain and Christensen 1989, Zandt and Ammon 1995, Koch 1992). Christensen (1996) has classified the typical values of $V p / V s$ for various rock types. For example, the low values $(\sim 1.70)$ represent felsic rocks (i.e., granite), the intermediate values $(\sim 1.78)$ and the high values $(\sim 1.84)$ are values for intermediate rocks (e.g., diorite) and mafic rocks (e.g., basalt), respectively. Thus, we suggest that the crust in Timor Island might be dominated by mafic and ultramafic bodies which might be derived from the Banda forearc basement or lower plate of the Australian continental margin, as suggested by geological and gravity studies (Kaye 1989, Ishikawa et al. 2007, Harris 2011). Furthermore, the low velocity gradient found in the lower crust with high $V p / V s$ ratio might be related to the serpentinisation of some basic rocks during collision between Australian passive margin and volcanic arc, which may produce a mafic and ultramafic precursor for the movement of thrust sheets (Kaye 1989). Christensen and Salisbury (1975) reported that the typical values of the $V p / V s$ ratio are higher than 2 for serpentinized and very serpentinized ultra mafic rocks and less than 1.95 for mafic rocks. In West Timor, a geological investigation reported the existence of spinel peridotites, recrystallized partly to tremolite-talc and serpentine schist, and mafic rocks (Helmers et al. 1989). The gravity study suggests that these rocks might have been carried ashore by obducting mantle during the later stage of collision (Kaye 1989).

We found that the Moho depth beneath two stations (ATNI and SOEI) is of about 34-37 km obtained from the NA inversion and $H-k$ stacking. These results are comparable to those obtained by other studies and reflect the influence of continental character (Milsom and Audley-Charles 1986, Bowin et al. 1980). However, for station BATI located in the southwestern part of the island, the results show a shallower Moho depth, of $\sim 28 \mathrm{~km}$, with low $V p / V s$ ratio. This can be explained that strong reflection appearing at $\sim 3-4 \mathrm{~s}$ on the receiver functions might correspond to the Australian lower crust inserting beneath southern part of Timor, as suggested by Kaye (1989) rather than Moho discontinuity. Thus, this strong reflection masks the Moho conversion phase causing ambiguous results for the NA and $H-k$ inversions.

\subsection{Sumba Island}

Sumba Island is located to the south of volcanic arc within the forearc basin and lies at the border of the transition zone between the subduction of the Indo-Australian oceanic lithosphere along the Sunda margin in the west and the collision of the Australian continent margin with the Banda arc in the 
east. The location of Sumba Island is separated by two deep forearc basins, the Lombok Basin to the west and the Savu Basin to the east. The major geologic formation of Sumba Island contains volcanic, plutonic, and volcaniclastis rocks (Rutherford et al. 2001). These rock formations record the volcanic activities that began at around $80 \mathrm{Ma}$ or earlier and ceased at around $31 \mathrm{Ma}$ (Rutherford et al. 2001, Abdullah et al. 2000). Tectonic studies suggest that Sumba Island is considered as a micro-continent or continental fragment detached from its origin and drift away to its current position (Hamilton 1979, Abdullah et al. 2000). Sumba Island ceased moving and started to rise when the Australian continental crust collided with the Banda Arc at $8 \mathrm{Ma}$ (Rutherford et al. 2001, Keep et al. 2003). Keep et al. (2003) suggested that the uplift of Sumba might be governed by the continent-arc collision tectonic process, as the buoyant of promontory Australian continental crust resisted to subduct and underplated beneath Sumba. As a consequence, this continued tectonic process has led to the Australian continental crust colliding with the thickened continental crust (as result of underplated product) beneath the island.

The Moho depth beneath the Island obtained from the NA inversion and $H-k$ stacking analysis varies from approximately 32 to $36 \mathrm{~km}$. This estimation is consistent with the typical values of the continental character (Christensen and Mooney 1995). The island is also characterized by the presence of low velocity zone in the lower crust with high $V p / V s$. Low velocity with high negative gradient on velocity profile indicates the presence of fluids (Mosalve 2013). In this case, the fluids can be water or partial melts. However, it is still difficult to say that the lower crustal low-velocity zone beneath this Island is attributed to high temperature fluids related to the geothermal activities, because the volcanic activities in this area ceased at $31 \mathrm{Ma}$ (Abdullah et al., 2000). As the uplifted Sumba Island might be influenced by the Australian Plate, the interaction between the deeper part of crustal root underneath Sumba and the finger of Australian continental crust might cause frictional strength at the plate boundary. Thus, we consider that the frictional process created the weak or fracture zone in the lower crust. The presence of fracture zone containing fluid might increase the $V p / V_{s}$ ratio. Conversely, the porous fracture zone might reduce the $V p / V s$ ratio (Wang 2012, Kaypak 2008). High $V p / V s$ ratios due to the crack fabric have been reported in other regions, for example, by Matsubara et al. (2008) and Kodaira et al. (2004). Matsubara et al. (2008) observed high $V p / V s$ in the lower crust of southwestern (SW) Japan through seismic tomography, which they interpreted as due to the high pore-fluid pressure resulting from the dehydration of fluid from the oceanic crust of the Philippine Sea plate beneath SW Japan. Other seismic tomography studies performed in the subduction zone in Japan and Cascadia also found low velocity zone with high $V p / V s$ in- 
terpreted as regions with high pore fluid pressure (Kodaira et al. 2004, Audet et al. 2009). Furthermore, laboratory measurements proposed that high $V p / V s$ with low velocity may be due to high pore fluid pressure and crack anisotropy or mineral alignment (Bezacier et al. 2010, Wang et al. 2012).

The presence of low velocity zone in the lower crust beneath Sumba Island may affect the genesis of earthquakes. The plot of the shallow events extracted from the EHB catalogue (Engdahl et al. 1998, http://www.isc. ac.uk) shows that the earthquakes are mainly concentrated above the lower crust in the eastern part of the island (Fig. 10). This suggests that the frictional process, as a result of the interaction between the crustal root under-
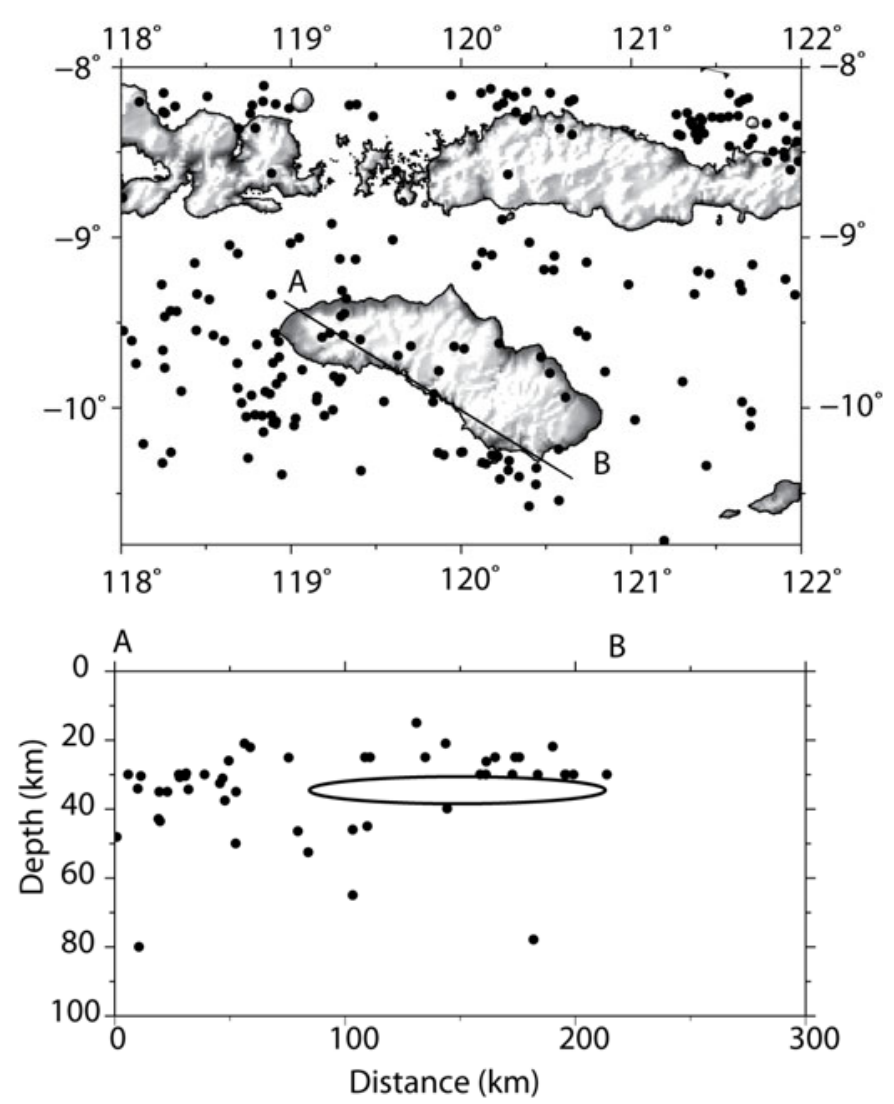

Fig. 10. Top panel shows the epicenters of the shallow events extracted from the EHB catalogue around Sumba Island. The A-B black line represents the position of cross section shown in bottom panel. The black ellipse in bottom panel indicates the low crustal low velocity layer. 
neath Sumba and the finger of Australian continental crust, may increase the temperature along the crustal boundary, causing the lower crust to deform aseismically. As also observed by other studies (e.g., Bai et al. 2015, Chiarabba and Amato 1996), the seismogenic layer is almost confined above the low crustal low velocity layer. Bai et al. (2015) observed that there are no earthquakes in the lower crust beneath Central Tibet, which they suggest that this could be due to the presence of partial melting in the lower crust as a result of the plate convergence. Chiarabba and Amato (1996) also found that the relocated events in the Northern and Southern Apennines are mainly concentrated above the low velocity of the lower crust. These researches lead to the conclusion that the lower crust under such condition may not be cold enough to produce earthquakes. However, further investigation involving larger local seismic data around Sumba Island is necessary in order to substantiate the role of this velocity zone to the earthquake generation process.

\subsection{Sumbawa and Flores Islands}

Sumbawa and Flores Islands are part of active magmatic inner Sunda-Banda arc. The volcanic arc has been accommodated by northward subduction of Indo-Australian crust. Recently, in eastern part of the arc, including Sumbawa and Flores, collision between Australian continent crust with Banda arc modified the shape of the arc, leading to the idea of subduction polarity reversal north of Flores and Sumbawa (Hamilton 1977, McCaffrey 1988). Bowin et al. (1980) suggested that the eastern part of Sunda-Banda arc lies on the oceanic crust. It was suggested that the crustal thickness in this region is more than $22 \mathrm{~km}$, which is greater than that of normal oceanic crust (Prasetyo 1992). However, other works suggested that the insertion of Australian continental character underneath southern part of the Banda arc might elevate the crustal thickness (Richardson and Blundell 1996, Keep 2003). From our analysis, we observed that the Moho depth derived from the NA inversion and $H-k$ stacking is about $28 \mathrm{~km}$ and $30-34 \mathrm{~km}$ beneath Sumbawa and Flores Islands, respectively. The deeper Moho depth beneath Flores Island might be due to a consequence of arc-continent collision. This inner arc region is also characterized high $V p / V s$ ratio $(>1.8)$ and low velocity zone in the upper and mid crust as observed in stations beneath Flores Island. We suggest that those might be due to the presence of magmatic materials ascending from the subducted slab to the volcanic islands. 


\section{CONCLUSION}

Here we presented the crustal properties and velocity structure derived from teleseismic receiver function using the non-linear NA inversion and $H-k$ stacking from twelve permanent seismic stations around Sunda-Banda arc transition zone. We obtained that the Moho depth at this transition zone is ranging from $28 \mathrm{~km}$ beneath Sumbawa Island to $37 \mathrm{~km}$ beneath Timor Island. We suggest that the thicker crustal thickness observed beneath Sumba and Flores Islands might be related to the arc-continent collision, in which the underplating of buoyant Australian crust during the arc-continent collision in southern part of the Banda arc increases the crustal thickness, as suggested by Richardson and Blundell (1996) and Keep (2003). In Timor and Sumba Islands, we observed relatively high $V p / V s$ ratios with the presence of low velocity zone in the lower crust. In Timor Island, we suggest that they might be related to the serpentinisation of some basic rocks during the arc-continent collision producing mafic and ultramafic bodies, as suggested by previous studies (Helmers et al. 1989, Kaye 1989). Whereas in Sumba they can be associated with the presence of fluid filled fracture zone due to interaction in the plate boundary between the deeper crust of Sumba and the underplated Australian continental crust (Keep 2003, Fleury et al. 2009). High $V p / V s$ ratios are also observed in Sumbawa and Flores Island which may correlate to the magmatic activies in the subducted slab.

Acknowledgments. This research was supported by the AIFDRGREAT-ITB and LIPI. We acknowledge Indonesian Agency for Meteorology, Climatology, and Geophysics (BMKG) and GFZ Potsdam for providing the data used in this study. We also thank R.B. Herrmann, C.J. Ammon, Malcolm Sambridge and K.C. Eagar for providing softwares used in this study. We also benefited from discussion with J. Julio. 


\section{Appendix}

\section{Receiver function plots as a function of event backazimuth}
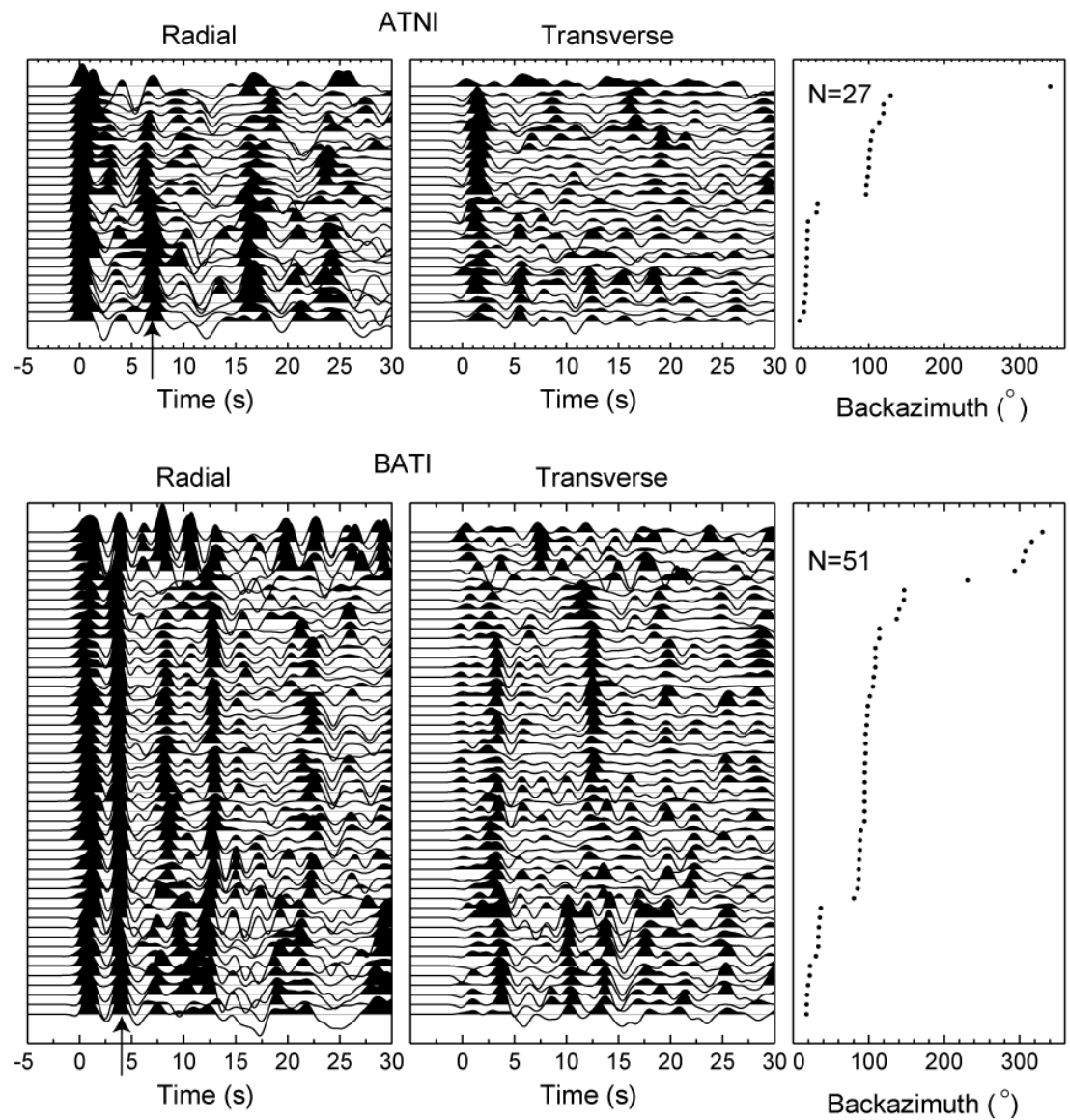

BATI

Transverse
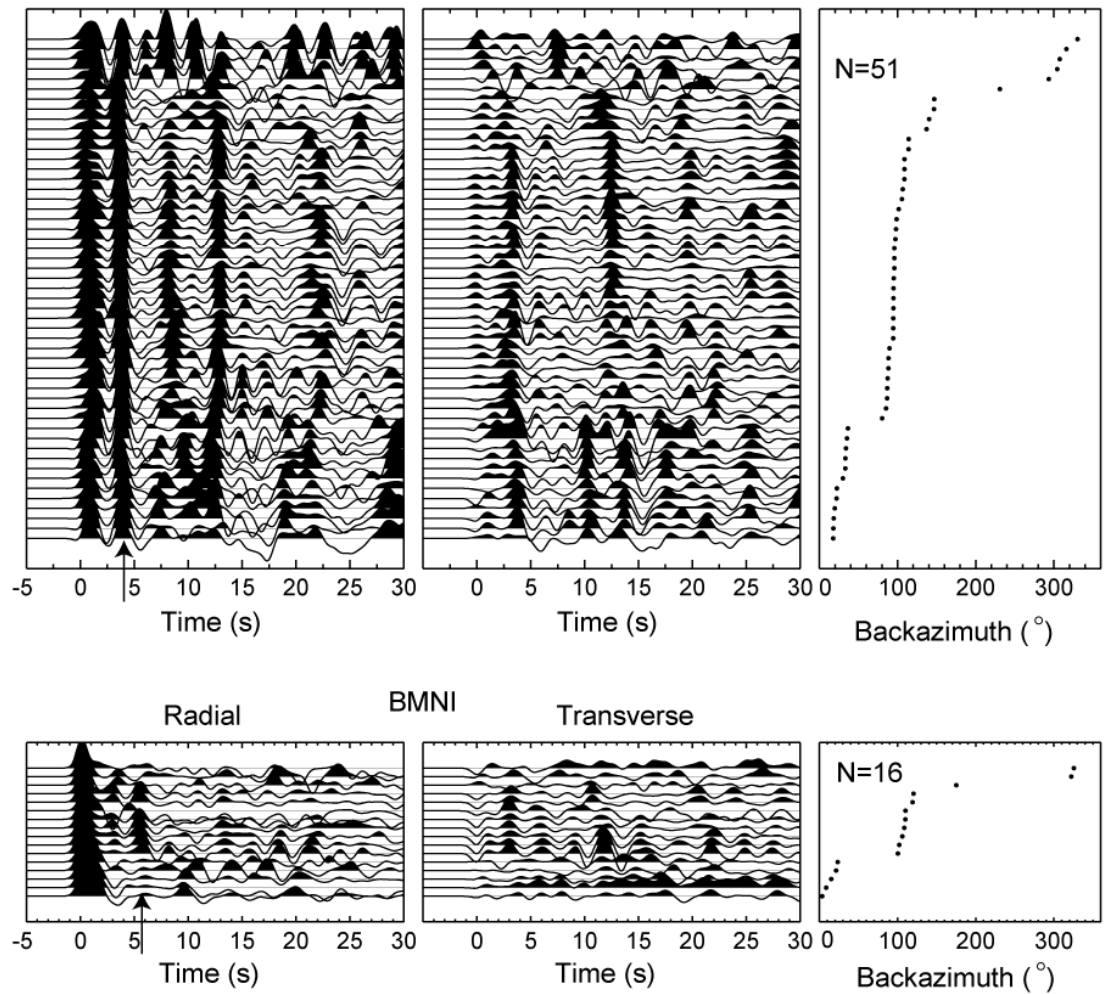

$\mathrm{BMNI}$
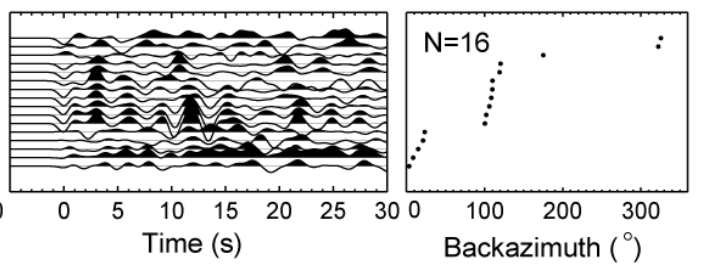

Fig. A1. Receiver functions at stations ATNI, BATI and BMNI plotted with equal spacing as a function of backazimuth. The black arrow in the left panel marks the PS phase. 

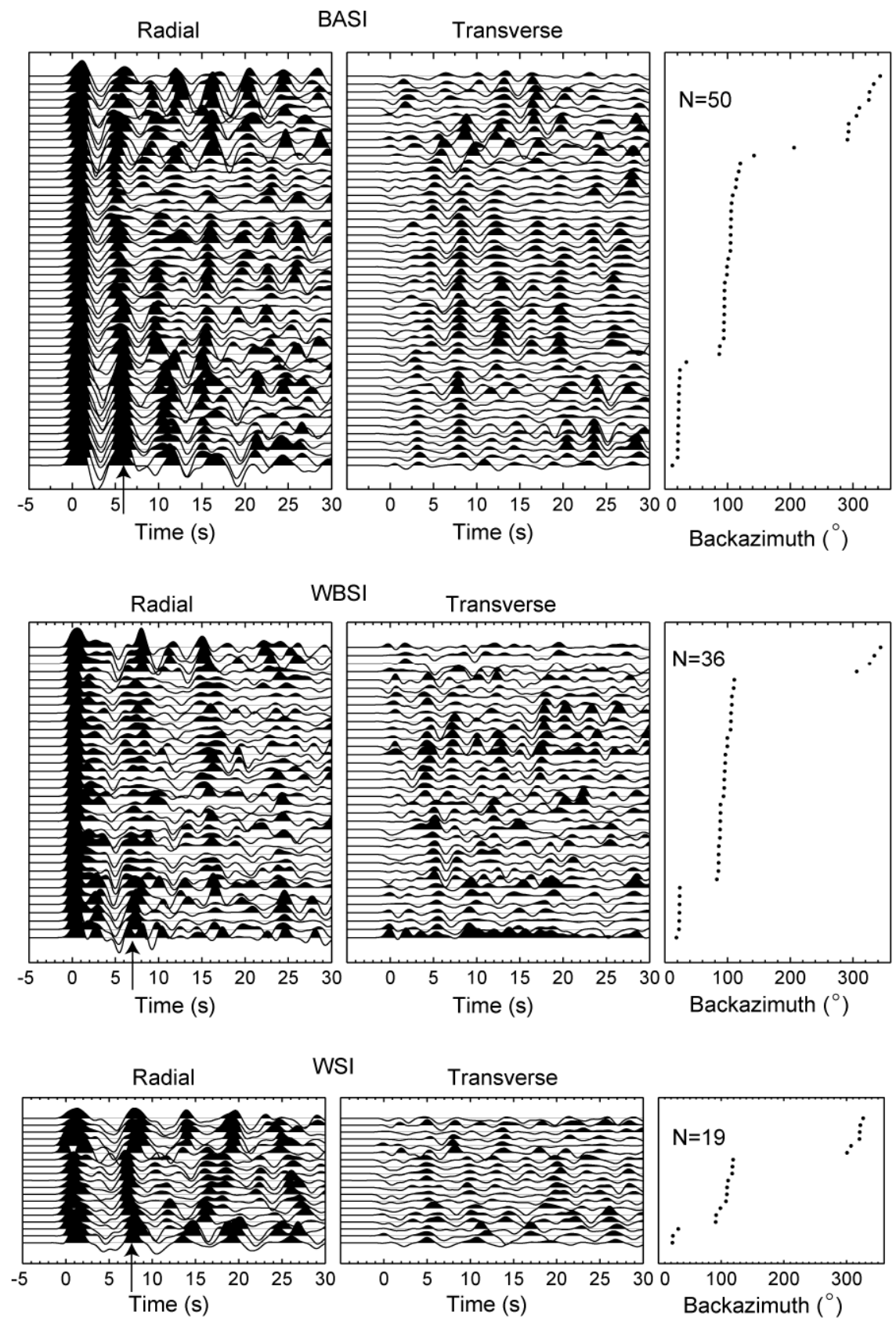

Fig. A2. Receiver functions at stations BASI, WBSI and WSI plotted with equal spacing as a function of backazimuth. The black arrow in the left panel marks the PS phase. 


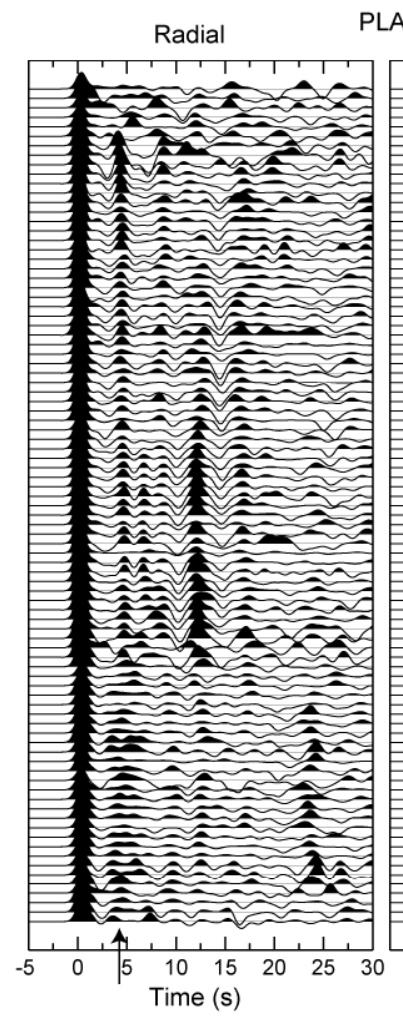

PLAI Transverse

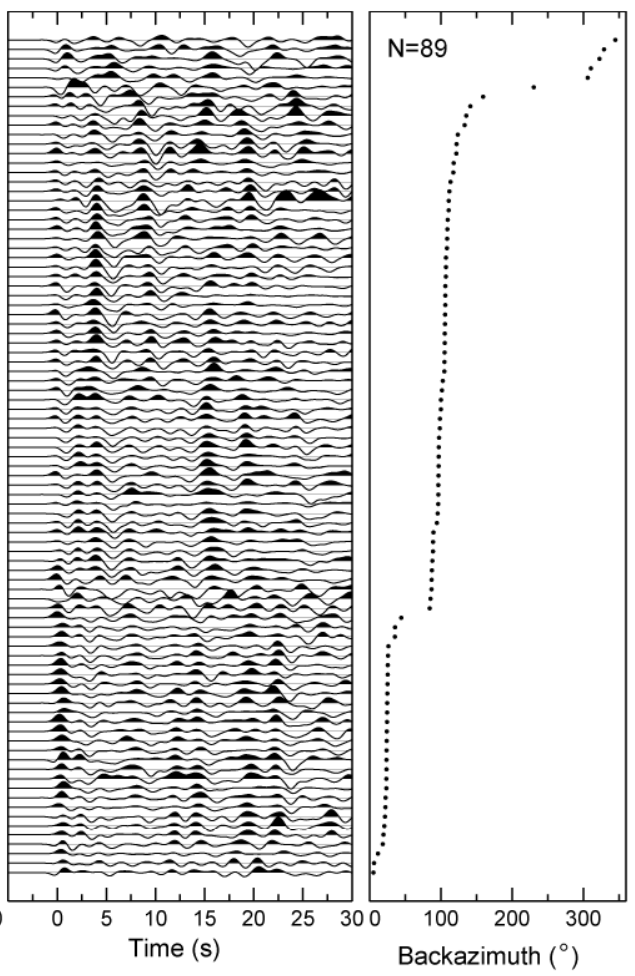

Radial

DBNI

Transverse
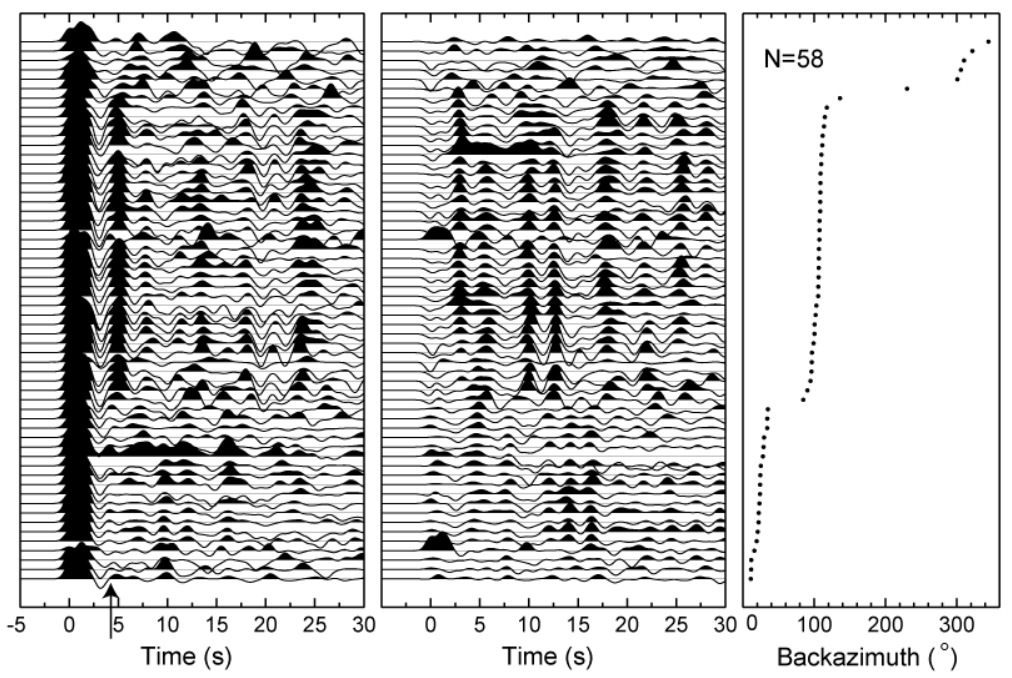

Fig. A3. Receiver functions at stations PLAI and DBNI plotted with equal spacing as a function of backazimuth. The black arrow in the left panel marks the PS phase. 


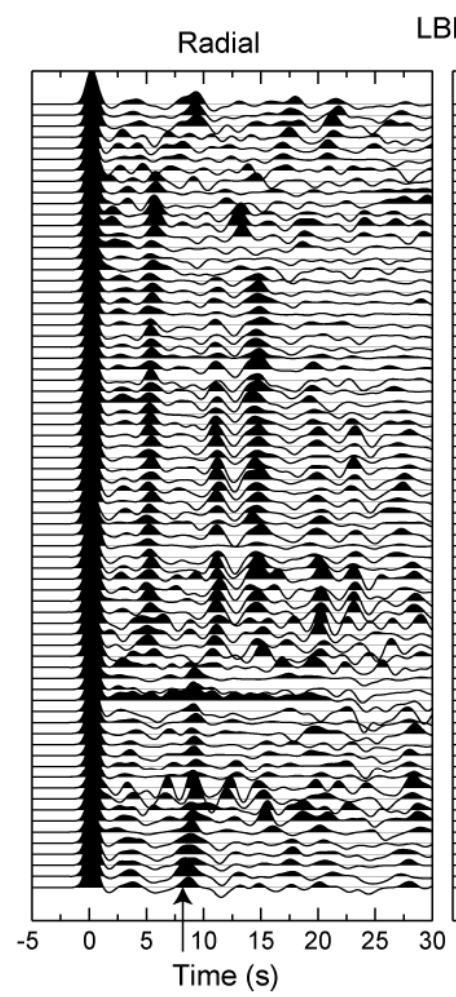

LBFI

Transverse
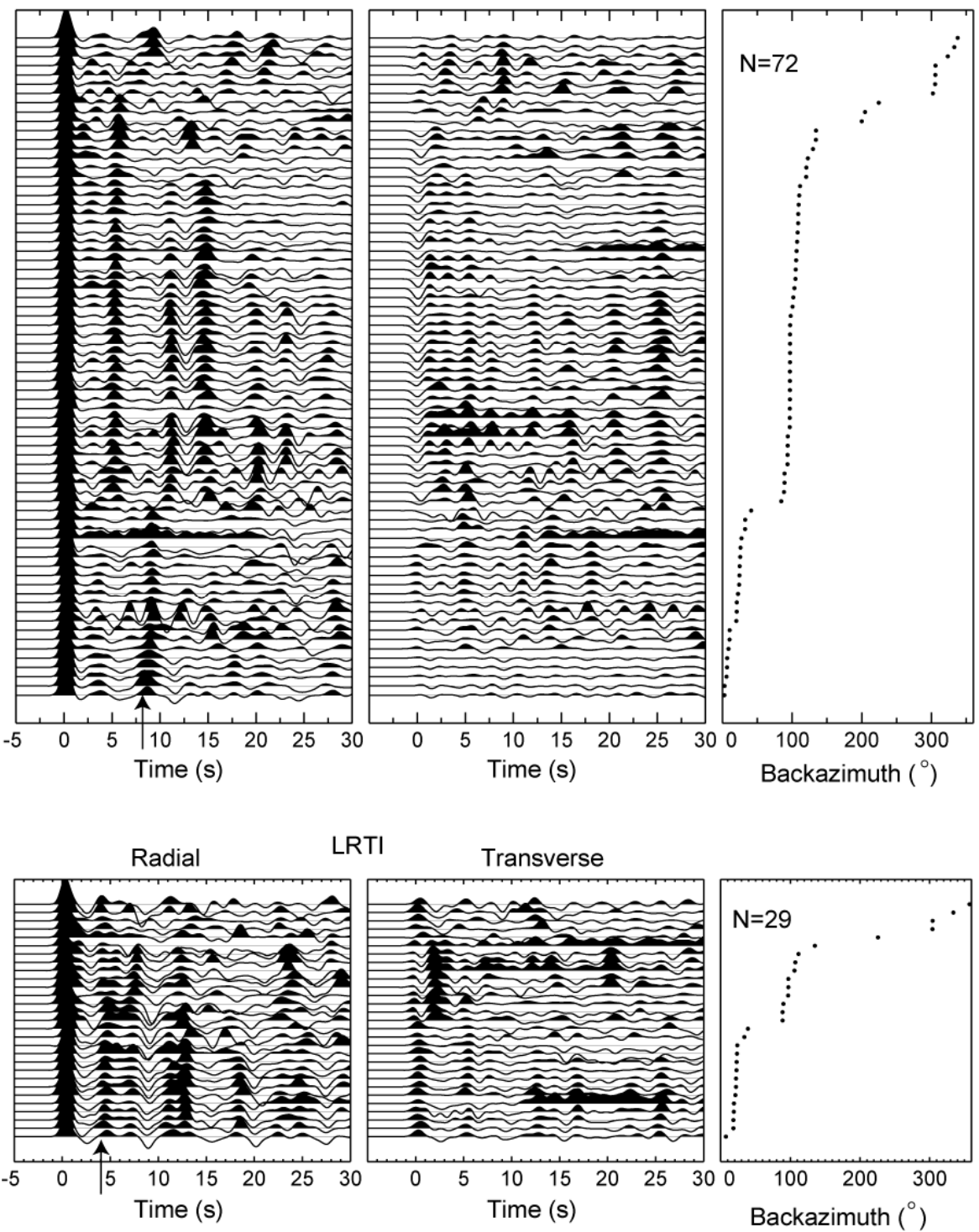

LRTI

Transverse

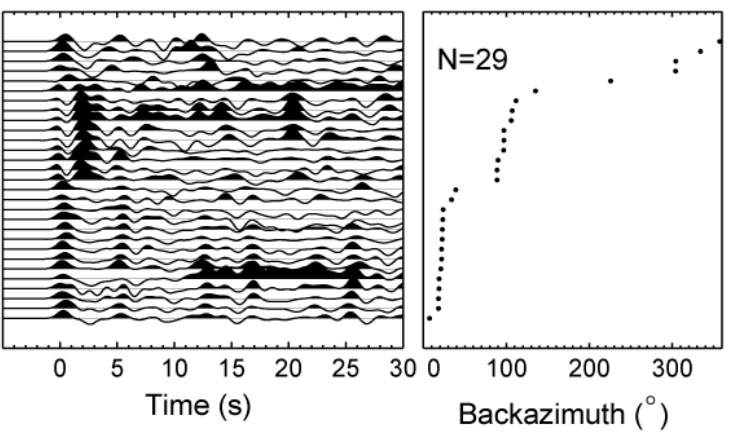

Fig. A4. Receiver functions at stations LBFI and LRTI plotted with equal spacing as a function of backazimuth. The black arrow in the left panel marks the PS phase. 


\section{References}

Abdullah, C.I., J.-P. Rampnoux, H. Bellon, R.C. Maury, and R. Soeria-Atmadja (2000), The evolution of Sumba Island (Indonesia) revisited in the light of new data on the geochronology and geochemistry of the magmatic rocks, $J$. Asian Earth Sci. 18, 5, 533-546, DOI: 10.1016/S1367-9120(99)00082-6.

Ahmed, A., S. Leroy, D. Keir, F. Korostelev, K. Khanbari, F. Rolandone, G. Stuart, and M. Obrebski (2014), Crustal structure of the Gulf of Aden southern margin: Evidence from receiver functions on Socotra Island (Yemen), Tectonophysics 637, 251-267, DOI: 10.1016/j.tecto.2014.10.014.

Ammon, C.J. (1991), The isolation of receiver effects from teleseismic P waveforms, Bull. Seismol. Soc. Am. 81, 6, 2504-2510.

Audet, P., M.G. Bostock, N.I. Christensen, and S.M. Peacock (2009), Seismic evidence for overpressured subducted oceanic crust and megathrust fault sealing, Nature 457, 7225, 76-78, DOI: 10.1038/nature07650.

Bai, L., G. Li, N.G. Khan, J. Zhao, and L. Ding (2015), Focal depths and mechanisms of shallow earthquakes in the Himalayan-Tibetan region, Gondwana Res., DOI: 10.1016/j.gr.2015.07.009 (in press).

Bannister, S., C.J. Bryan, and H.M. Bibby (2004), Shear wave velocity variation across the Taupo Volcanic Zone, New Zealand, from receiver function inversion, Geophys. J. Int. 159, 1, 291-310, DOI: 10.1111/j.1365246X.2004.02384.x.

Barber, A.J. (1981), Structural interpretations of the island of Timor, eastern Indonesia. In: A.J. Barber and S. Wiryosujono (eds.), The Geology and Tectonics of Eastern Indonesia, Special Publication of the Geological Research and Development Centre, Bandung, 183-197.

Barber, A.J., M.G. Audley-Charles, and D.J. Carter (1977), Thrust tectonics in Timor, J. Geol. Soc. Australia 24, 1, 51-62, DOI: 10.1080/ 00167617708728966.

Bezacier, L., B. Reynard, J.D. Bass, C. Sanchez-Valle, and B.V. Moortele (2010), Elasticity of antigorite, seismic detection of serpentinites, and anisotropy in subduction zones, Earth Planet. Sci. Lett. 289, 198-208, DOI: 10.1016/ j.epsl.2009.11.009.

Bowin, C., G.M. Purdy, C. Johnston, G. Shor, L. Lawver, H.M.S. Hartono, and P. Jezek (1980), Arc-continent collision in Banda Sea region, Am. Assoc. Petrol. Geol. Bull. 64, 6, 868-915.

Cassidy, J.F. (1992), Numerical experiments in broadband receiver function analysis, Bull. Seismol. Soc. Am. 82, 3, 1453-1474.

Charlton, T.R. (1989), Stratigraphic correlation across an arc-continent collision zone: Timor and the Australian Northwest Shelf, Aust. J. Earth Sci. 36, 2, 263-274, DOI: 10.1080/08120098908729485. 
Chiarabba, C., and A. Amato (1996), Crustal velocity structure of the Apennines (Italy) from P-wave travel time tomography, Ann. Geofis. 39, 6, 1133-1148, DOI: $10.4401 / \mathrm{ag}-4042$.

Christensen, N.I. (1996), Poisson's ratio and crustal seismology, J. Geophys. Res. 101, B2, 3139-3156, DOI: 10.1029/95JB03446.

Christensen, N.I., and W.D. Mooney (1995), Seismic velocity structure and composition of the continental crust: A global view, J. Geophys. Res. 100, B6, 9761-9788, DOI: 10.1029/95JB00259.

Christensen, N.I., and M.H. Salisbury (1975), Structure and constitution of the lower oceanic crust, Rev. Geophys. 13, 1, 57-86, DOI: 10.1029/ RG013i001p00057.

Darbyshire, F.A. (2003), Crustal structure across the Canadian High Arctic region from teleseismic receiver function analysis, Geophys. J. Int., 152, 2, 372391, DOI: 10.1046/j.1365-246X.2003.01840.x.

Eagar, K.C., and M.J. Fouch (2012), FuncLab: A matlab interactive toolbox for handling receiver function datasets, Seismol. Res. Lett. 83, 3, 596-603, DOI: 10.1785/gssrl.83.3.596.

Eagar, K.C., M.J. Fouch, D.E. James, and R.W. Carlson (2011), Crustal structure beneath the High Lava Plains of eastern Oregon and surrounding regions from receiver function analysis, J. Geophys. Res. 116, B2, B02313, DOI: 10.1029/2010JB007795.

Efron, B., and R. Tibshirani (1986), Bootstrap methods for standard errors, confidence intervals, and other measures of statistical accuracy, Stat. Sci. 1, 1, 54-77.

Efron, B., and R. Tibshirani (1991), Statistical data analysis in the computer age, Science 253, 5018, 390-395, DOI: 10.1126/science.253.5018.390.

Engdahl, E.R., R. Hilst, and R. Buland (1998), Global teleseismic earthquake relocation with improved travel times and procedures for depth determination, Bull. Seismol. Soc. Am. 88, 3, 722-743.

Fleury, J.M., M. Pubellier, and M. Urreiztieta (2009), Structural expression of forearc crust uplift due to subducting asperity, Lithos 113, 1-2, 318-330, DOI: $10.1016 / \mathrm{j}$. lithos.2009.07.007.

Fountain, D.M., and N.I. Christensen (1989), Composition of the continental crust and upper mantle: A review. In: L.C. Pakiser Jr. and W.D. Mooney (eds.), Geophysical Framework of the Continental United States, Geological Society of America, Memoir 172, Boulder, Colorado, 711-742.

Haig, D.W. (2012), Palaeobathymetric gradients across Timor during 5.7-3.3Ma (latest Miocene-Pliocene) and implications for collision uplift, Palaeogeogr. Palaeoclim. Palaeoecol. 331-332, 50-59, DOI: 10.1016/ j.palaeo.2012.02.032. 
Hall, R., and H.R. Smyth (2008), Cenozoic arc processes in Indonesia: Identification of the key influences on the stratigraphic record in active volcanic arcs, Geol. Soc. Am. Spec. Pap. 436, 27-54, DOI: 10.1130/2008.2436(03).

Hamilton, W. (1977), Subduction in the Indonesian region. In: M. Talwani and W.C. Pitman (eds.), Island Arcs, Deep Sea Trenches, and Back-ArcBasins, Maurice Ewing Series 1, American Geophysical Union 1, Washington, 1531.

Hamilton, W. (1979), Tectonics of the Indonesian Region, Geological Survey Professional Paper 1078. U.S. Government Printing Office, Washington D.C.

Harris, R. (2011), The nature of the Banda arc-continent collision in the Timor region. In: D. Brown and P.D. Ryan (eds.), Arc-Continent Collision, Frontiers in Earth Sciences, Springer, Berlin Heidelberg, 163-211, DOI: 10.1007/978-3-540-88558-0_7.

Harris, R.A., and M.G. Audley-Charles (1987), Taiwan and Timor neotectonics: a comparative review, Mem. Geol. Soc. China 9, 45-61.

Helmers, J., J. Sopaheluwaken, S. Tjokrosapoetro, and E.S. Nila (1989), High grade metamorphism related to peridotite emplacement near Atapupu, Timor, with reference to the Kaibobo peridotite on Seram, Indonesia, Neth. J. Sea Res. 24, 2-3, 357-371, DOI: 10.1016/0077-7579(89)90161-0.

Ishikawa, A., Y. Kaneko, A. Kadarusman, and T. Ota (2007), Multiple generations of forearc mafic-ultramafic rocks in the Timor-Tanimbar ophiolite, eastern Indonesia, Gondwana Res. 11, 1-2, 200-217, DOI: 10.1016/j.gr.2006.04. 007.

Jones, C.H., and R.A. Phinney (1998), Seismic structure of the lithosphere from teleseismic converted arrivals observed at small arrays in the southern Sierra Nevada and vicinity, California, J. Geophys. Res. 103, 10065-10090, DOI: $10.1029 / 97 J B 03540$.

Julia, J., M. Assumpcao, and M.P. Rocha (2008), Deep crustal structure of the Parana' Basin from receiver functions and Rayleigh-wave dispersion: Evidence for a fragmented cratonic root, J. Geophys. Res. 113, B8, B08318, DOI: $10.1029 / 2007$ JB005374.

Kaye, S.J. (1989), The structure of Eastern Indonesia: an approach via gravity and other geophysical methods, Ph.D. Thesis, University of London.

Kaypak, B. (2008), Three-dimensional VP and VP/VS structure of the upper crust in the Erzincan basin (eastern Turkey), J. Geophys. Res. 113, B7, B07307, DOI: $10.1029 / 2006 J B 004905$.

Keep, M., I. Longley, and R. Jones (2003), Sumba and its effect on Australia's north-western margin, Geol. Soc. Austral. Spec. Publ. 372, 309-318, DOI: 10.1130/0-8137-2372-8.309.

Koch, M. (1992), Bootstrap inversion for vertical and lateral variations of the $\mathrm{S}$ wave structure and the Vp/Vs-ratio from shallow earthquakes in the 
Rhinegraben seismic zone, Germany, Tectonophysics 210, 1-2, 91-115, DOI: 10.1016/0040-1951(92)90130-X.

Kodaira, S., T. Iidaka, A. Kato, J.-O. Park, T. Iwasaki, and Y. Kaneda (2004), High Pore fluid pressure may cause silent slip in the Nankai Trough, Science 304, 5675, 1295-1298, DOI: 10.1126/science.1096535.

Levin, V., and J. Park (1998), P-SH conversions in layered media with hexagonally symmetric anisotropy: a cookbook, Pure Appl. Geophys. 151, 669-697, DOI: $10.1007 / \mathrm{s} 000240050136$.

Ligorría, J.P., and C.J. Ammon (1999), Iterative deconvolution of teleseismic seismograms and receiver function estimation, Bull. Seismol. Soc. Am. 89, 5, 1395-1400.

Linkimer, L., S.L. Beck, S.Y. Schwartz, G. Zandt, and V. Levin (2010), Nature of crustal terranes and the Moho in northern Costa Rica from receiver function analysis, Geochem. Geophys. 11, Q01S19, DOI: 10.1029/2009GC002795.

Macpherson, K.A., D. Hidayat, and S.H. Goh (2012), Receiver function structure beneath four seismic stations in the Sumatra region, J. Asian Earth Sci. 46, 161-176, DOI: 10.1016/j.jseaes.2011.12.005.

Matsubara, M., K. Obara, and K. Kasahara (2008), Three-dimensional P- and Swave velocity structure beneath the Japan Islands derived from the highdensity seismic stations by seismic tomography, Tectonophysics 454, 1-4, 86-103, DOI: 10.1016/j.tecto.2008.04.016.

McCaffrey, R. (1988), Active tectonics of the eastern Sunda and Banda arcs, J. Geophys. Res. 93, B12, 15163-15182, DOI: 10.1029/JB093iB12p15163.

Milsom, J., and M.G. Audley-Charles (1986), Post-collision isostatic readjustment in the southern Banda Arc. In: M.P. Coward, and A.C. Ries (eds.), Collision and Tectonics, Geological Society, Spec. Pub., Vol. 19, 353-364, DOI: 10.1144/GSL.SP.1986.019.01.20.

Mosalve, H., J.F. Pacheco, C.A. Vargas, and Y.A. Morales (2013), Crustal velocity structure beneath the western Andes of Colombian using receiver-function inversion, J. South Am. Earth Sci. 48, 106-122, DOI: 10.1016/j.jsames. 2013.09.001.

Owens, T.J. (1984), Determination of crustal and upper mantle structure from analysis of broadband teleseismic P-waveforms. Ph.D. Thesis, Department of Geology and Geophysics, The University of Utah, USA.

Planert, L., H. Kopp, E. Lueschen, C. Mueller, E.R. Flueh, A. Shulgin, Y. Djajadihardja, and A. Krabbenhoeft (2010), Lower plate structure and upper plate deformational segmentation at the Sunda-Banda arc transition, Indonesia, J. Geophys. Res. 115, B8, B08107, DOI: 10.1029/ 2009JB006713.

Prasetyo, H. (1992), The Bali-Flores Basin, geological transition from extensional to subsequent compressional deformation. In: Proc. 21st Annual Convention Indonesian Petroleum Association, 455-478. 
Richardson, A.N., and D.J. Blundell (1996), Continental collision in the Banda arc, In: R. Hall and D.J. Blundell (eds.), Tectonic Evolution in Southeast Asia, Geological Society of London, Spec. Publ. 106, 47-60, DOI: 10.1144/GSL. SP.1996.106.01.05.

Rutherford, E., K. Burke, and J. Lytwyn (2001), Tectonic history of Sumba Island, Indonesia, since the Late Cretaceous and its rapid escape into forearc in the Miocene, J. Asian Earth Sci. 19, 4, 453-479, DOI: 10.1016/S1367-9120(00) 00032-8.

Sambridge, M. (1999), Geophysical inversion with a neighbourhood algorithm- I. Searching a parameter space, Geophys. J. Int. 138, 2, 479-494, DOI: 10.1046/j.1365-246X.1999.00876.x.

Sandwell, D.T., and W.H.F. Smith (2009), Global marine gravity from retracked Geosat and ERS-1 altimetry: Ridge Segmentation v. spreading rate, $J$. Geophys. Res 114, B01411, DOI: 10.1029/2008JB006008.

Shulgin, A., H. Kopp, C. Mueller, E. Lueschen, L. Planert, M. Engels, E.R. Flueh, A. Krabbenhoeft, and Y. Djajadihardja (2009), Sunda-Banda arc transition: Incipient continent-island arc collision (northwest Australia), Geophys. Res. Lett. 36, 10, L10304, DOI: 10.1029/ 2009GL037533.

Spasojevic, S., and R.W. Clayton (2008), Crustal structure and apparent tectonic underplating from receiver function analysis in South Island, New Zealand, J. Geophys. Res. 113, B4, B04307, DOI: 10.1029/2007JB005166.

Wang, H.Q., A. Schubnel, J. Fortin, E.C. David, Y. Gueguen, and H.K. Ge (2012), High Vp/Vs ratio: Saturated cracks or anisotropy effects?, J. Geophys. Res. 39, 11, L11307, DOI: 10.1029/2012GL051742.

Yeck, W.L., A.F. Sheehan, and V. Schulte-Pelkum (2013), Sequential H-k Stacking to obtain accurate crustal thicknesses beneath sedimentary basins, Bull. Seismol. Soc. Am. 103, 3, 2142-2150, DOI: 10.1785/0120120290.

Zandt, G., and C.J. Ammon (1995), Continental crust composition constrained by measurements of crustal Poisson's ratio, Nature 374, 6518, 152-154, DOI: $10.1038 / 374152 \mathrm{a} 0$.

Zheng, T., L. Zhao, and L. Chen (2005), A detailed receiver function image of the sedimentary structure in the Bohay Bay Basin, Phys. Earth Planet. Int. 152, 3, 129-143, DOI: 10.1016/j.pepi.2005.06.011.

Zhu, L., and H. Kanamori (2000), Moho depth variation in southern California from teleseismic receiver functions, J. Geophys. Res. 105, B2, 2969-2980, DOI: 10.1029/1999JB900322. 